Ministry of Education and Science of Ukraine

Ternopil Ivan Puluj National Technical University

(full name of higher education institution)

Economics and Management

(faculty name)

Innovation Activity and Services Management Department

(full name of department)

\title{
EXPLANATORY NOTE
}

for Master's Thesis

"THE MECHANISM OF ATTRACTING FOREIGN

topic:

INVESTMENTS FOR THE DEVELOPMENTS OF INNOVATIVE ACTIVITY (COCA-COLA COMPANY AS A CASE STUDY)"

\begin{tabular}{|c|c|c|}
\hline Submitted by: sixth & year student & IBUm-61 \\
\hline Specialism (field of & study) & 073 "Management" \\
\hline "Managen & $\frac{\text { lent of inno }}{\text { me of specializat }}$ & $\frac{\text { vation activity" }}{\text { ion (field of study)) }}$ \\
\hline & & $\begin{array}{c}\text { Ikeahvu Favour } \\
\text { Kelechi }\end{array}$ \\
\hline & (signature) & (surname and initials) \\
\hline Supervisor & & Vovk I.P. \\
\hline & (signature) & (surname and initials) \\
\hline Compliance check & & Stoiko I.I. \\
\hline & (signature) & (surname and initials) \\
\hline Reviewer & & \\
\hline & (signature) & (surname and initials) \\
\hline
\end{tabular}




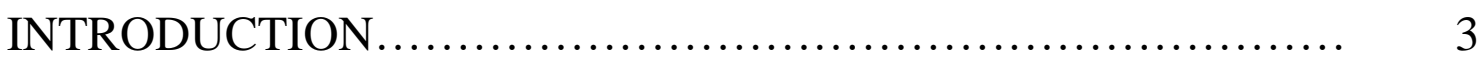

1. THEORETICAL ASPECTS OF ENTERPRISES INNOVATIVE DEVELOPMENT ................................................. 5

1.1. Theoretical basis of innovative activity........................ 5

1.2. Foreign investment as an important component of innovative activity....................................................... 12

1.3. Methods of research......................................... 15

2. ANALYTICAL EVALUATION OF THE COCA COLA

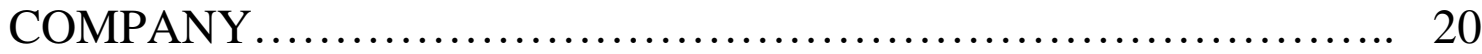

2. 1. General characteristics of the enterprise ...................... 20

2.2. Analysis of industrial and economic activity of the enterprise..... 26

2.3. Co-operation between the Coca-Cola Enterprise and the Service 33 Industry

3. FINDINGS AND RECOMMENDATIONS...................... 37

3.1. Recommended mechanisms for attracting foreign investment for 37 innovative activity in the Coca-Cola enterprise

3.2. Recommendations for improvement of economic activity at CocaCola 43

3.3. Recommendations for the management of the company.......... 44

3.4.Recommendations for the management of the company 48

4. LABOUR PROTECTION AND SAFETY IN EMERGENCIES..... 51

4.1.Occupation Health in the workplace.......................... 51

4.2. Emergency plan at the workplace........................... 52

CONCLUSIONS ............................................... 55

REFERENCES.............................................. 57 


\section{INTRODUCTION}

The more modern conditions for enhancing the functioning of an enterprise hinge on the intellectual technologies that provide knowledge and information for the functioning of an enterprise [6, p.3]. This brings the need for innovation to the forefront. Innovative activity, on the micro and macro levels, is, without doubt, a core necessity for enterprises that crave to reach attain certain levels of achievement and success; this occurs through systematic and purposeful innovative activities geared towards seeking out opportunities that affect the production and introduction of new products, new industry, transport, development of new markets and new forms of organization [6, p. 1]. It is for this reason that the formulation and development of mechanisms that foster innovative activity in an enterprise are at the core of academic, economic, and other domestic and international discourse. Foreign investment is a tool utilized by countries as well as multinational entities and in the transfer of knowledge - encompassing new technologies, materials, production methods, or organizational management skills - to emerging markets [7, p. 2]. From the 1990s, foreign investment has been a vital source of resource to the economies of less developed countries, however, this practice extends to corporate enterprises as well. Foreign investment plays an oversize role in building business viability and in the promotion of innovation, this explains why governments invest maximally in attracting foreign investment to their economies. However, while the role of foreign investment in the development of national economies has been a subject of constant discourse, it is apposite to examine the importance of foreign investment to enterprises. This work sets out to define the necessity of foreign investment to the development of innovative activity in an enterprise, then hitching on methods, strategies, policies, etc. which may be adopted in attracting foreign investment to enterprises.

This study seeks to address the problem of [the need for] innovative activity in the enterprise; it x-rays the activities and organization of Coca-Cola, placing it side by side with the need for innovative activity in the enterprise, crafting strategies for the attraction of foreign investment to the enterprise. In the development of these 
strategies, due regard shall be had to the peculiarities of the organization in the light of its reach, size, revenue, regulatory hurdles, and general organizational culture.

In attaining the objective of this study, there will be extensive review and analysis of sources - general, primary, secondary, and others - relevant to the subject and the object of the research, also highlighting the pitfalls. From there, I will conclude methods, strategies, and factors that will enhance innovative activity through foreign investment. 


\section{CHAPTER 1 \\ THEORETICAL ASPECTS OF ENTERPRISES INNOVATIVE \\ DEVELOPMENT}

\subsection{Theoretical basis of innovative activity.}

Innovative activity - scientific, technological, organizational, financial, and commercial - affects the productivity of any enterprise; with the highly competitive atmosphere cutting across all sectors, innovation is key to enterprises that do not intend to be left behind [2, p 2].

Innovative activity is regarded as potentially one of the most important conditions for the formulation of competitiveness strategy by enterprises; with the introduction of enterprise, there is bound to be an upward movement in the competitiveness of products (goods and services), rates of development, and profitability [3, p. 47]. In understanding the subject of innovative activity, various writers have offered well-researched ideas on the concept, its various aspects, and various factors that determine its functionality in any enterprise.

Eurostat explains the concept of innovative activities to refer to "all scientific, technological, organizational, financial and commercial steps which actually or are intended to, lead to the implementation of innovations." [5]. The authors go further to indicate the mere engagement in these supposed activities does not without more confer on the proposed product the status of innovation; to be regarded as an innovation, the product, service or other endeavors must have been implemented. the nature of implementation is not uniform as it may differ depending on the nature of the innovation. Arefieva, et al., explain that innovative activity extends beyond changes in the qualitative characteristics of the enterprise and extends further to the creation of new consumption qualities; these qualities are predicated on the needs of the individuals engaged in the activity than creating a ripple effect that pervades production and non-production endeavors and this involves the use of new technology and innovative management approaches, based on the expectation of future changes or 
advancements in that sphere [4, p. 3]. Innovative activity is the process of creating a new product from formulating its idea to mastering production, producing, implementing, and obtaining a commercial effect [1]. The definitions of Arefieva and that of Clarysse convey the impression that innovations are targeted at solving problems and providing for the needs of the consumers.

Balabanov in describing the concept, refers to it as "an indicator of an enterprise movement towards the formation of competitive advantages, since it is the implementation of innovations under the conditions of the rapidly changing external world and the limited resources that determine the further corporative development [16]. This definition emphasizes competitiveness as the core purpose of innovative activity, the need to keep the enterprise in the race for supremacy among a [usually] large pool of competing businesses, creates the need for innovation. Authors like Karagiannis agree with this line of thought and as such, tips innovation as part of a wide range of systemic factors with a hand in the increment of competitiveness of products [17].

Balabanov weights in on the widely held assumption that innovative activities relate exclusively to Information Technologies (IT). The author argues that innovative activities are employed in any circumstance where it becomes necessary to create solutions to problems that face the industrial sector of the economy. In support of this notion, the use of power purchase agreements (PPA) (which establishes a power generation system and provides its maintenance on the buyer's territory) has been put forward as an instance of the utilization of innovation outside the core areas of IT. This does not however discountenance the fact that PPA's have been utilized by companies within and outside the sphere of information technology.

Goncharenko, et al., describes innovations - which are the end product of such activities - as "a new or significantly improved product (goods or services) or process, a new sales method or a new organizational method in business practices, workplace organization or in external relations, which has been brought into use [11]. Akshmetin et al., defined innovation to mean a process, a set of consecutive actions aimed at bringing the advanced scientific idea to the stage of its practical application and 
obtaining economic benefits [9]. Prigogine in his definition paints a picture of innovation as a purposeful change. He writes, "First, the goals of change are determined, innovation is developed, if necessary, it is tested, then it is mastered and distributed, and finally, it "dies out", exhausted morally or physically [10]. His definition conveys the finite lifespan of innovation, hence a need for constant innovation which meets up with changing economic, social, or scientific circumstances. Kotler defines the concept of innovation as an idea, product, or technology launched in mass production and presented on the market, which the consumer perceives as completely new or possessing some unique properties. The authors in defining innovation do limit the term to the creation of new products alone, rather, the addition of new features to existing products suffices as an innovation in this context. A typical example is the frequent addition of features and software upgrades enhancing already existing functions or adding new functions to mobile devices without necessarily removing the product from circulation and replacing it with new ones. Despite the agreement of the authors concerning the scope of innovation extending to new and existing products, there is a disparity in thought in these definitions, especially the definitions of Akshmetin and Prigogine. The former hinges the concept of innovation on the practicalisation of a scientific idea; hence, development is an innovation only where it is the result of a scientific idea - a scientific idea brought to life. Prigogine on the other hand makes no such distinction. In the opinion of this author, development is an innovation where it is a harbinger of purposeful change - solves a need - regardless of its scientific nature or otherwise.

Innovative activities occasion a transformation of not just the enterprise, but its surroundings as well - the client, the competitors, and the market. The need for innovation, hence innovative activities, flows from the need to maintain competitiveness [32]. In this regard, the enterprise strives to add to its retinue of skills, knowledge, and principles that its competitors do not have.

Kovalenko, et al., posits that innovation and innovative activity are interrelated concepts distinguished only by the existence of a process approach - a system of actions aimed at turning knowledge into a useful product - in the latter. In analyzing 
the concept of innovation, Aydalot and Keeble determine that two approaches may well be derived from the definition of innovation:

1. As to the process of introducing innovations

2. The result of human activity in the form of new products, technologies, methods, etc. [8].

However, the first of the two approaches put forward by Aydalot and Keeble 'the process of introducing innovations' is what has come to be understood as innovative activity - as gleaned from the definitions above [9].

According to Endovitskii \& Gilyarovskaya, management is at the core of corporate innovation activity, so much so that it retains a spot as an important tool in enhancing the competitiveness of various economic entities - states and enterprise and as an effective source of their successful operations, increasing profitability and investment attractiveness while growing market attractiveness [18].

In the study of innovative activity in an enterprise, certain authors are proponents of a likely relationship between the rate of innovative activity and the size of the enterprise. However, there is a disagreement as to how the size of an enterprise affects the innovative activity within its organization. Hence the question of which is amenable to innovation, large enterprises or small enterprises?

In addressing this throbbing issue, Chandy $\&$ Tellis, rely on the theory of inertia to argue that the size of an enterprise is of direct proportion to its innovative appetite [12]. They write that "large firms are less likely to provide the responsive, risk-taking atmosphere needed for the development of radical innovations." This theory postulates that smaller firms tend to be more innovative as they are characterized by a flexible climate for quicker decision making and this allows its members to make audacious moves towards more creative projects, a higher ability to reflect on opportunities, and little to no difficulty in implementing necessary change [13]. In the same vein, Cohen and Klepper state that the tendency to perform research and development (R\&D) is commensurate to the size of the firm, more times, this tends to decline as the firm increases in size [14]. It is on this basis that Ferencz and Dugas concluded that small 
and medium enterprises play increasingly significant roles in creating and applying innovations [15].

Some other authors take to the opposite opinion. They argue that large firms are more innovative and that this is linked to their significant financial and technical capabilities. Other factors that may positively affect innovative activity in large enterprises are the economies of scale and top-tier hiring capabilities (larger firms due to the higher compensation and career advancement opportunities they afford, can pick the best from any pool of professionals). The proponents of this theory take to the view that innovation and development projects in larger enterprises are less susceptible to failure, as such failure if even it occurs, will occasion lesser impact on the finances of the enterprise as against the impact of such failure on the finances on smaller enterprises. To this end, Love, et al., conclude that plant size, foreign ownership, and the presence of $R \& D$ (factors readily existent in larger enterprises), have a positive impact on innovative activity. The authors view the size of an enterprise as a factor that encourages innovations [20]. A growing number of studies have sided with the later postulation, to wit, the size of an enterprise is proportionate to the innovative drive of the enterprise [19].

Our findings indicate the existence of a positive statistically significant relationship between the size of a firm and innovation activity that seems to be rather nonlinear. The nonlinearity can be explained by contradictory tendencies in the form of the advantage of large enterprises by generating resources necessary for innovations on the one hand, and the advantage of small and medium enterprises in flexibility and motivation to innovations on the other. It can be assumed that firm size does matter for innovation activity. Although the results of this study find more of a positive relationship between size and innovation activity, it is not sufficient to conclude that big firms are better innovators than smaller firms. The nature of this relationship and its limits can also be analyzed more thoroughly with regards to differences in competitive behavior.

Bruothova, et al., conducted a study among manufacturing companies in the Slovak Republic. These companies under study were involved in the production of 
various products ranging from food and beverage, chemicals and chemical products, rubber and plastics, fabricated metal products, computer, electronic and optic products, motor vehicles, among others. The study would reveal that there is in existence a statistically consistent relationship between the size of a firm and the innovative activity it undertakes [21, p. 6-10]. However, it is observed that this relationship is nonlinear; while the smaller firms hold the advantage of flexibility and motivation, larger firms have deeper pockets and have at their disposal, the resources necessary for the undertaking of these activities.

In other words, although the size of the enterprise may affect the rate of innovative activity, none of the classes of enterprise holds a monopoly of effective innovation. Certain other individual factors existent and which are sometimes peculiar to the enterprises may then draw the line between those with a strong drive and propensity for innovative activity and those that do not have such an appetite for innovation.

Despite the importance of innovative activity, a plethora of factors affects the implementation of innovative activities in an enterprise. Arefieva, et al., recognizes those distinct factors that are likely to forestall the progress of innovative activity in any enterprise as follows:

a) The cost of research and development $(R \& D)$ projects. This is typically high, exacerbated by the [typically lengthy] duration of these projects, the limited number of enterprises capable of carrying out the projects, or disbursing funding sufficient to last till the maturity of these projects.

b) The reluctance of the state to support and fund the development and implementation of innovative products. The enterprise, especially the smaller enterprises are left holding the bag and given the high costs of these innovative endeavors, the enterprises may be unable to shoulder the costs of innovative activities.

c) The implementation of taxation as a factor to stimulate innovation has persistently been below par.

d) The lack of diversification of banking lending is due to the high interest rates of the projects. The high rates are a product of the uncertain duration and unpredictable 
results of these projects which present a potential risk of non-repayment of loans. Hence, the banking institutions are unwilling to give loans for such projects on flexible terms - this is perceived to be a cushion against the high level of risks associated with radical innovations.

e) The rapid depreciation of the capital prevents the discovery of technical and technological basis for their testing and introduction into the production process on qualitatively new grounds; there is also a need to train personnel of the appropriate qualification and capable of perceiving innovations.

f) There is grave difficulty in accurately ascertaining the demand for innovative products. This would track back to other subfactors such as the flexibility in market demand, and the high cost of market research.

In a nutshell, the problems highlighted above revolve around core issues of financing, government regulation, and organizational management. This study will address the issue of financing for innovative activities, specifically, the place of foreign investments in the growth of innovative activities in enterprises.

On the issue of threats to the innovative activities, Goncharenko, et al., posits that:

a) Innovations may result in a steep decline in client confidence following the implementation of innovations. The clients and stakeholders are skeptical of the eventual success of the innovations, hence the potential to draw back from activities that portend any potential for risk to the investments or expected returns from the products of the enterprise. This is supported by a PwC study which observed that 67 percent of managers of the largest companies in the world expect a drop in customer confidence upon the implementation of innovations in artificial intelligence and blockchain [22].

b) Innovations are often accompanied by risks of cyberattacks, opening the systems and information of the clients up to potential data thieves, given the fact that a vast majority of innovative activity takes place digitally through computers and computerized tools or over the internet. This creates a need for the organization to completely step up its protection against these risks [11]. 
Bearing in mind the treats occasioned by these innovative activities, Nechaev, highlights the problems of developing innovative activities to include:

a) Risks;

b) High cost;

c) Long-term return on innovation;

These factors considered cumulatively creates the need that risk management strategies be a fundamental part of the activities. The number of risk kinds would vary with the structure of the organization; hence, innovations must encompass risk assessment techniques to help the companies create tools of maximum quality, and also operational risk analysis of innovation which creates an avenue for the neutralization of possible risks in the future.

\subsection{Foreign investment as an important component of innovative activity.}

In discourse surrounding innovative activity in enterprises, funding has been fingered as a factor affecting the rate of innovation in an enterprise. Chen defines foreign investments as involving 'capital flows from one country to another, granting foreign investors extensive ownership stakes in domestic companies and assets' [23]. The concept denotes the active participation of foreigners in the management of the enterprise on account of their investments in the enterprise.

Seen as a catalyst for economic growth, foreign investments in any entity may be direct or indirect. Foreign Direct Investments (FDI) are physical investments in the enterprise which may include the establishment of plants and the purchase of machinery or other direct financial injection into the capital flow of the company by the foreign investor. Meyer defines FDI as the ownership of an asset in one country by the resident of another country. It is the purchase of a significant part of an enterprise by an investor located outside of its national borders [24].

Indirect investments, on the other hand, are characterized by the purchase of shares or positions in the enterprise against any direct or specific injection of capital. However, this form of foreign investment is less desirable. This undesirability flows 
from the fact that the company in which the investment is made can easily sell off its investment. Hence, this study will focus principally on FDI and the mechanisms for its attraction.

According to the OECD, FDI forms "an integral part of an effective international economic system and a major catalyst to development", but it wastes no time in drawing attention to the fact that FDI although beneficial, does not yield its benefits all at once [75 p. 3]. The benefits from activities resulting from FDI accrue over time. These benefits may include income growth and productivity of enterprise in the host country. The OECD, in discussing the concept of FDI, highlights trade and investment, technology transfers, human capital enhancement, competition, and enterprise development as the areas where the impact is most felt:

a) Trade and Investment:

The effects of FDI on the host enterprise may differ depending on the host enterprise and the factors present and affecting the activities that make up the FDI process. However, the OECD agrees based on empirical evidence that the primary benefit of FDI on trade in developing countries is that it behooves long term contributions to the integration of the host enterprise and the larger economy [75, p. 10]. However, the OECD cautions that stakeholders must not be fixated on these long-term benefits; regard must be had for the short term and medium-term implications of the trade activities as well. The short-term effects include the cost of creating and maintaining EPZ's and the risks associated with the creation of an uneven playing field between the domestic enterprises and the foreign enterprise and the chances that the opening up of the economy vide trade and investments arising from FDI, will result in international bidding tussles.

b) Technology Transfers

Technology transfer is perceived predominantly as the most important means of positively affecting the productivity of the host enterprise in the FDI process. In the process of making foreign direct investments in the enterprise, the companies - which are mostly more technologically advanced that the countries in which they invest - are bound to make commitments which amount to technological spillovers [75, p. 12]. In 
demystifying technology transfer, the OECD identifies the four interrelated channels within which the process occurs [75, p. 13]:

i. Vertical linkages with suppliers or purchasers in the host enterprise;

ii. Horizontal linkages with competing or complementary companies in the same industry;

iii. Migration of skilled labor;

iv. The internationalization of research and development.

c) Human Capital Enhancement

In order to attract FDI, the receiving enterprise must create an environment that is compatible with the level of investment it envisages. From this flows the need for the development of human capital. The workforce in the enterprise seeking investments must be educationally qualified for the employment opportunities that become available upon the arrival of investments. On this basis, FDI affects the enhancement of human capital - although not directly, as is mostly obtainable.

d) Competition

With the increase in market concentration which occurred as a response to the wave of mergers and acquisitions that characterized the 1990's, the global corporate landscape has changed significantly. This phenomenon has seen the development of alliances between enterprises and an increase in privatization, which have had noticeable effects on competition. The concentration of enterprises has the capacity to reduce competition in the markets to which the investments flow. It must be noted however that the impact of FDI on competition is not uniform but will vary with the sector involved.

e) Enterprise Development

The rate of enterprise development in the host enterprise is bound to increase alongside foreign direct investments in that enterprise. This impact may be recognized in the enhanced co-operation within the investor enterprise, the efforts at efficiency and cost reduction, and the development of new activity [75, p. 17]. In the way, there is a direct link between FDI and the promotion of innovative activity.

The discussion on these areas of contact between FDI and the enterprise, points to the fact that the practice of FDI flows mostly to countries from other countries or 
from multinational companies to the countries but it is not very common a practice for companies to the core recipients of FDI - although they can be recipients. Also, FDI is not limited to the transfer of material resources like finance and machinery; it may also encompass the transfer of skill and technology know-how.

Lagendijk and Hendrikx, acknowledge FDI as the prevalent mode of corporate governance to gain control of properties abroad [25]. This control is achieved through the transfer of property rights to the foreign firm. The authors state that apart from control over companies abroad, the second aim of FDI is to improve ownershipspecific advantages by anchoring in foreign technological hot spots. The impacts of FDI on the host regions or enterprises include higher employment levels, linkages, knowledge spillover, and innovation. Shah, et al., in commenting on the concept estimated the FDI outflows from three of the largest economies in the world - the United States, China, and India [2015].

The flow of FDI has significant impacts on the export of technology, and then innovation [26]. This is achieved in a variety of ways as expanded below:

a) The establishment of $R \& D$ facilities in the foreign countries

b) The transborder mergers and acquisitions that would usually flow from FDI are principal ways to fill technological gaps and improve the innovative capability of the respective enterprises.

c) These transborder technological alliances may result in the creation of new technologies.

\subsection{Methods of research.}

In the conduct of this study, the researcher will adopt the research process onion as propounded by Saunders, et al. [27]. These methods, although not perfect provides a rounded perspective of methodology in research [28]. The methods provide a template for a suitable research methodology. The study will identify and justify the selected research approach, research philosophy, research strategy, research methodology, sources of data, methods, and type of data analysis, the time horizon of 
study, tools of data analysis as well as other research options available. This is in line with research methodologies as propounded by Saunders, et al. [27].

The research study embraces the pragmatic research philosophy. The research theory of pragmatism involves using theories to identify solutions to the subject of the research. secondary sources of data/information to examine events and their consequences on a sample population [27]. The philosophy places a larger emphasis on the outcome of the study over and above the ideas behind the research hence, the approach will enable a proper understanding of the research problem and lead to a balanced conclusion. This study principally seeks to understand the role of foreign investment in the development of innovative activities and develop strategies to spur the inflow of these investments.

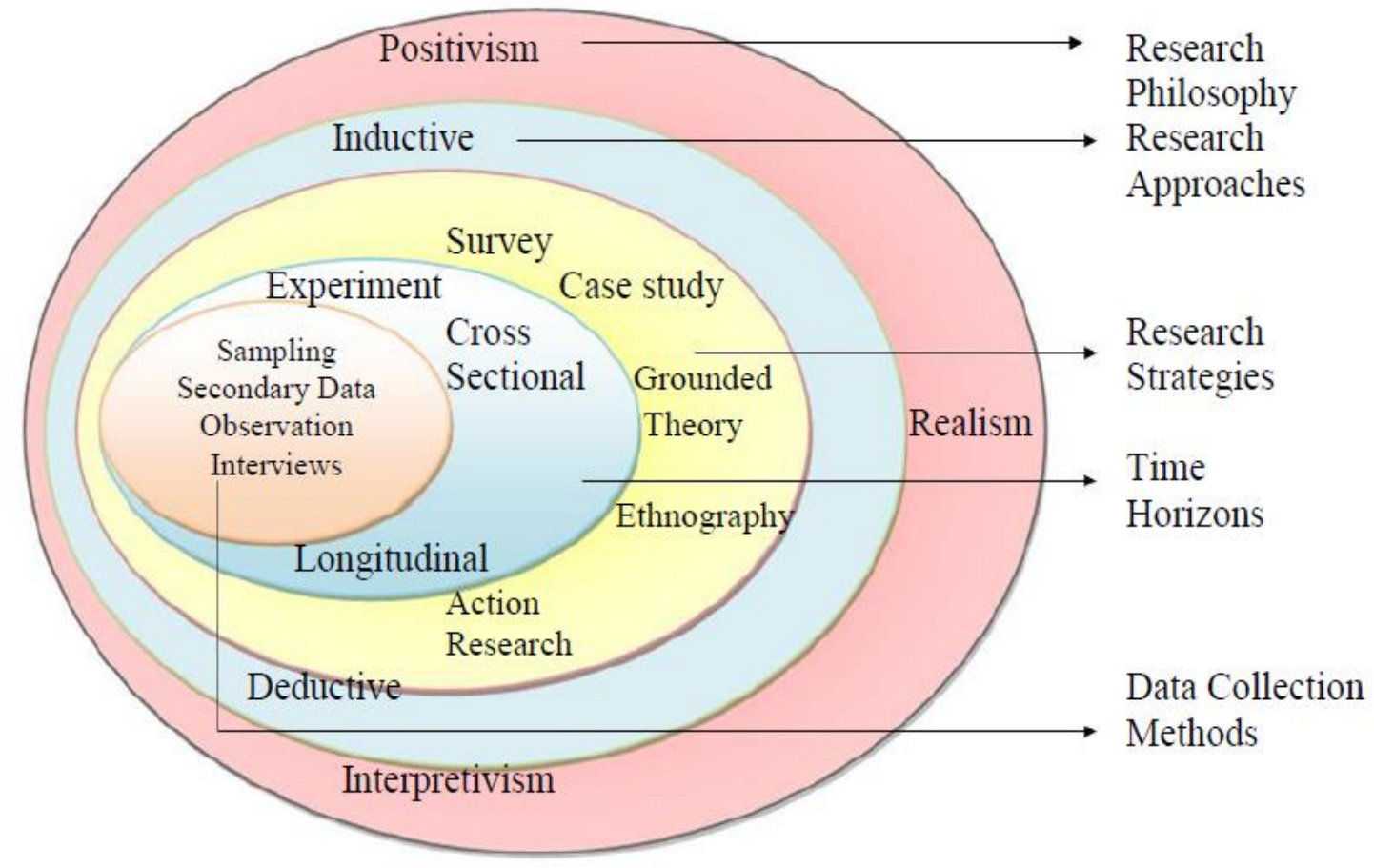

Figure 1. Research process onion

The research methodology as expressed by Saunders which will govern this research study is represented under the sub-headings below:

The study will adopt an action research strategy. Using the action research strategy, a researcher is engaged in developing solutions to specific problems. The strategy of this research focuses primarily on the object of the research, particularly on weaknesses related to the interactions with the real world [27]. The research ends with solutions to these problems affecting the object [29]. On this basis, the research will 
study the issue of innovative activity on Coca-Cola or the lack thereof to craft workable mechanisms to propelling innovative activity through foreign investment.

The research approach of the study is the deductive research approach. The deductive research approach involves the development of theory and hypotheses that are then tested through the use of a specific research strategy [27]. In deductive reasoning is considered to be reliable on account of the properly structured methodology within which it exists. The conclusion always follows a set of premises; where the premises are proven, the conclusion is true. Saunders, et al., highlights five stages of inductive research:

a. Forming the hypotheses

b. Deducing premises that can be tested

c. The premises are then examined along with the logic of the argument from which they proceed after which they are connected to the existing theories.

d. The premises are then tested by the collection of data from which the variables and concepts are measured

e. Analysis of the results. From this analysis, it is determined if the theories are consistent with the theory and from there, a decision is made on whether the theory is accepted or rejected.

This study would observe the steps outlined under this approach and will conclude the specific strategies for the development of innovative activities through foreign investment, these conclusions will be drawn from the best possible arguments and premises from past studies and research.

The study uses the qualitative research methodology rather than a quantitative research methodology or a mixed approach. The qualitative methodology, also referred to as 'market research is closely linked to the preferred deductive approach and it revolves around data obtained through open-ended and conversational communication [30]. Unlike quantitative methodology, qualitative methodology is shown to be more in-depth in obtaining precise specifics and information from the respondent population/sample size. The qualitative methodology digs deep into not just what people think, but why they hold such opinion(s). This methodology uses cases and 
context to examine social processes, examining social life from various points of view and looking to how people construct identities, rarely taking variables into account.

This study will take feature interviews, focus groups, record keeping, and other qualitative methods. However, in doing this, recourse will be made to already establish information and knowledge in the field from which projections will be made on the role of foreign investments in enterprise innovation activity.

The major source of data for the study and to conduct its analysis is the secondary source of data. Secondary data may be drawn from organization databases, communications, websites, minutes and reports of meetings, media accounts as contained in television and radio broadcasts and other news articles, census, market trends, surveys, case studies, and other private polling, etc. [27]. In carrying out this study, the researcher will collect data from various secondary sources which demonstrate the role and degree of innovative activity in the enterprise. From the data drawn from these sources, the study will track the impact of foreign investments on the growth of innovative activities in the enterprise. The disadvantage of secondary sources of data collection is that the reliability and credibility of the data can be questioned/challenged since the author did not directly retrieve the data.

Flowing from the exposition on secondary sources explaining the sources from which data will be drawn, below are sources from which data used in the course of this research will be obtained:

Statista: This provides insights and facts cutting across various subjects, including those subjects which are relevant to this study. The data provided by this service cut across over 150 countries hence the advantage of providing a holistic perspective of the subject of the research.

Organization for Economic Cooperation and Development Foreign Investment Statistics: This source provides global and local data and analysis on the flows of FDI across economies and enterprises. With the data provided, the research will make sense of foreign investments as they relate to innovation in the enterprise.

World Bank Foreign Direct Investment Data: The data source combines data from the International Monetary Fund, Balance of Payments database supplemented 
by data from the United Nations Conference on Trade and Development, and official national sources to give insight into the inflows and outflows of FDI into various economies.

European Statistics: All European statistics are available on this database, allowing the researcher to make proper analysis on relevant activities e.g., the growth of innovative activities in enterprises.

The types of data analysis include qualitative content, narrative, discourse, thematic, grounded theory, and interpretive phenomenological analysis. However, this study revolves around the innovative activities of the select enterprises and the role of FDI in the development of these activities, hence the suitability of thematic analysis to this study. In this method, the research will dig into patterns of meaning in a given data set [31]. This method is particularly useful where the research revolves around the experiences of persons or other entities concerning the objects of the research. In this study bordering on the impact of FDI on innovative activity in enterprises, the research study will draw evaluate the responses of entities that have, as drawn from the secondary sources. From this evaluation, the study will bring to the fore specific themes that resonate with those enterprises which have employed these tools. 


\section{CHAPTER 2.}

\section{ANALYTICAL EVALUATION OF THE COCA COLA COMPANY.}

\subsection{General characteristics of the enterprise.}

The history of the Coca cola company dates to 1886 . In this year, a pharmacist by the name of John Pemberton sold in his small pharmacy, the soft drink he had invented. During this venture, he sold portions of his business to different persons and other entities, including Asa Candler, an Atlantan businessman, who had the lion share of the company by the time Pemberton died in 1888. In its earliest stages, the soft drink was sold in a glass but would be served in bottles in no time; this initiative was invented and pursued by Joseph Biedenharn. By 1889, the trio of Benjamin Thomas, John Lupton, and Joseph Whitehead - who had secured bottling rights to the product from Chandler at the cost of one dollar - reorganized the product and added the newly developed Coca Cola bottling system. In its earliest marketing efforts, Coca Cola used its famous slogan "the pause that refreshes" on newspaper advertisements. By 1923, the company had begun producing and marketing Fanta, the first soft drink besides Coca-Cola to be marketed by the company and as time progressed, the enterprise extended its reach beyond soft drinks with its acquisition of other beverage brands, creating an appeal to customers who had various tastes.

In over a century, the Coca-Cola has been revolutionized from the little-known neighborhood elixir of Dr. Pemberton, into the undisputed leader of the non-alcoholic beverage industry, operating in over 200 countries and embodying over 500 brands all over the world which include Ade Soy-based beverages, Ayakata green tea, Coca-Cola drinks, Dasani Waters, Del Valle juices and nectars, Fanta, Georgia Coffee, Honest tea, Minute Maid juices, Powerade sports drinks, Simply juices, Smart water, Sprite, Zico coconut water, etc. -21 of which generate over 1 billion USD in sales annually. CocaCola ranks as one of the largest private employers in the world with an employee payroll of over 700,000; on a day-to-day basis, the company records sales within the 
range of 1.9 billion products. The company operates in all countries of the world, except for Scotland, with the regions delimited into segments:

a) Africa, Europe, and the Middle East

b) Asia Pacific

c) North America

d) Latin America

e) Corporate

f) Bottling Investments Operating Segment

The North American segment is the company's flagship market and boasts over 370 million customers and an industry value of approximately 216 billion USD [33].

The Coca-Cola company has no sole ownership, rather it is a publicly listed company, owned by its shareholders - who run into thousands - with American billionaire investor, Warren Buffett being its largest shareholder [34]. The executive leadership of the enterprise is composed of professionals well vested in various areas, ranging from economics, public policy, finance, law, etc. At the helm of affairs is James Quincey, the Chairman and Chief Executive Officer, who took over leadership of the enterprise in 2017. Prior to assuming this position, Quincey had in several positions he managed within the Coca-Cola organization, immersed himself substantially in the workings of the enterprise, its strengths and weaknesses, its efforts at re-franchising and was a perfect fit to lead the organization through its progressive experience as the largest beverage enterprise in the world. The top management of the Coca-Cola organization is represented below [35]:

a) James Quincey - Chairman and CEO

b) Brian Smith - President and Chief Operating Officer

c) John Murphy - Executive Vice President and Chief Financial Officer

d) Manuel Arroyo - Global Chief Marketing Officer

e) Stacy Apter - Vice President, Corporate Treasurer

f) Barry Ballow - Vice President, Internal Audit

g) Marcelo Boffi - President, Bottling Investment Group

h) Henrique Braun - President, Latin America 
i) Jorge Garduno - President, Japan and South Korea

j) Nikolaos Koumettis - President, Europe

k) Claudia Lorenzo - President, ASEAN and South Pacific

1) Vamsi Mohan Thati - President, Greater China and Mongolia

m) Bruno Pietracci - President, Africa

n) Sanket Ray - President, India and Southwest Asia

o) Alfredo Rivera - President, North America

p) Evguenia Stoichkova - President, Eurasia and Middle East

q) Selman Careaga - President, Global Coca-Cola Category

r) Lisa Chang - Global Chief People Officer

s) Monica Howard Douglas - Senior Vice President and General Counsel

t) Jeffrey Gilbert - Vice President and Chief Security Officer

All over the world, over 700,00 people are employed at Coca-Cola, its subsidiaries and bottling partners [77]. These individuals that make up the workforce cut across numerous ethnic groups, racial identities, nationalities, and religions; this creates a multi-cultural environment within the enterprise. Given the multicultural setting, the Coca-Cola enterprise pays close attention to racial equity, recognizing the racial differences in the multi-cultural atmosphere it creates [76].

Apart from racial and cultural inclusion among its workforce, the Coca-Cola enterprise has shown a willingness to engage in societal discourse and patriotic activity. In demonstration of this zeal to add value to society, during the second world war, the enterprise devoted itself to providing a Coke to every soldier in the field of battle for just a nickel. In pursing this policy - which was part of a larger campaign to make the product available to all persons, irrespective of race, gender, or class - the company did not mind the financial implications to the company [77]. In the same way, in 1969, the Coca-Cola 'Boys on the Bench' advertisement was a powerful [and timely] statement in support of racial inclusion and diversity [77]. This advertisement, which was the first of the enterprise to feature African American and white people, drove home the message of inclusion and against segregation and other racial injustices. 
The Coca-Cola enterprise has also been keen in its support for athletic events and athletes. Far back as 1928, the Coca-Cola enterprise entered its first partnership with the US Olympic committee and sponsored the Olympic Games [78, p.1]. This has not ceased as the enterprise has since continued to lend a hand in support of the USA Olympic team, the International Olympic Committee and the US Olympic and Paralympic Committee; a commitment the enterprise is keen on maintaining for many years to come [78, p. 1]. Apart from the Olympics, the enterprise has been key in the funding and organization of other major sporting events - the FIFA Men's and Women's World Cups, the Special Olympics and the UEA Champion's League. This devotion of athletics is based on the belief in the power of sports to bridge the divides that exist among people while putting forwards the best attributes of the human spirit [78, p 1].

The Coca-Cola enterprise has not shied away from reaffirming its commitment towards human rights. This respect for human rights is at the root of all interactions with employees, bottling partners, customers, suppliers, and all other class of persons that encounter the Coca-Cola enterprise. The enterprise is committed to the United Nations Guiding Principles on Business and Human Rights, which enjoins businesses to strive to identify and address human rights risks to individuals and to communities situate across the Coca-Cola value chain [78, p. 2]. In the implementation of this mandate, the enterprise through a framework of policies, due diligence, and remediation processes, applying to all operations, partners, and subsidiaries, has instilled a consciousness towards human rights in its systems throughout the world [78, p. 2].

Coca-Cola has maintained profitability and stable growth over the years. At the end of the second quarter of 2021, the company reported strong numbers - a 42 percent growth in net revenues, 37 percent increase in organic revenues and a 52 percent growth in operating income. The enterprise gained a substantial part of the market for nonalcoholic ready-to-drink (NARTD) beverages, spurring an increase in market share and maintaining its place as leader of that market. There was as well as an increase in 
cash flow from operations by over 100 percent, up 5.5 billion USD from the 2.7 billion USD recorded in 2020 [36].

The enterprise has witnessed a growth in the value of its assets by over 100 percent in the last dozen years, up 87.2 billion USD in 2020 from 40.5 billion USD in 2008. This has not however been a tale of increase without downturns as there had been a significant bump to 92.02 billion USD in 2014 (the highest of the enterprise's asset value in over a decade), which soon took a glide towards 83.2 billion USD by 2018 [36].

(Millions of US Dollars)

\begin{tabular}{|c|c|}
\hline 2020 & 87,296 \\
\hline 2019 & 86,382 \\
\hline 2018 & 83,216 \\
\hline 2017 & 87,896 \\
\hline 2016 & 87,270 \\
\hline 2015 & 89,996 \\
\hline 2014 & 92,023 \\
\hline 2013 & 90,055 \\
\hline 2012 & 86,174 \\
\hline 2011 & 79,974 \\
\hline 2010 & 72,921 \\
\hline 2009 & 48,671 \\
\hline 2008 & 40,519 \\
\hline
\end{tabular}

\section{Table 1: Coca-Cola Annual Total Assets value [36]}

\section{Competitors}

Coca-Cola has been a dominate force in the beverage industry since the late $19^{\text {th }}$ century, leading the market in nonalcoholic beverages. For as long as it has been dominating, Pepsi has launched fierce opposition to the Coca-Cola enterprise; it is the first name that comes to mind in any discussion about the major competitors of the 
Coca-Cola company as both companies have fair shares of the market and staunch consumer loyalty [37]. However, despite the competition between the two in the beverage market, Pepsi lays claim to a variety of food brands in categories where CocaCola is not involved, snacks like Doritos, Lay's, Cheetos, Tostitos, and Fritos, amongst others [38].

Other competitors of the Coca-Cola enterprise include:

a) Keurig Green Mountain Group: The Keurig Dr Pepper group has a portfolio of over 125, owned, licensed, partner and allied brands in the beverage market and has attained is in its right a market leader in the single cup coffee market [39]. It produces brands like 7up, Schweppes, Crush, Squirt, Royal Crown Cola, Green Mountain coffee, etc. [40].

b) Tropicana Products: The company produces drinks from natural fruits of different flavors [41].

c) Britvic: The company specializes in the manufacture, marketing, and sale carbonated drinks. The company states in its production, it considers the health and lifestyle choices of its consumers, hence, the production of brands like Barley water, fruit cordial and Robinsons [42].

d) Red Bull: Specializing in energy drinks products, the company is responsible for the Red Bull energy drink and the Red bull sugar free [43].

e) Monster Beverage Corporation: This is a holding company which produces and markets various energy drinks through its subsidiaries. These products include Monster Energy drink, Monster Energy Ultra energy drinks, Monster MAXX maximum strength energy drinks, Java Monster non-carbonated coffee + energy drinks, Muscle Monster non-carbonated energy shakes, etc. [44].

f) Fever-Tree: Fever-tree specializes in mixers for alcoholic drinks and spirits. The mixers are products of naturally sourced ingredients. The brands include Damson $\&$ Sloe Berry Tonic Water, Indian Tonic Water, Light Cucumber Tonic Water, Light mixer, etc. [45].

Despite the existence of competition, the Coca-Cola far outweighs it competitors in valuation, market share, social standing, and size. Coca-Cola has remained 
seemingly unphased by the pressure from competition and this may be linked to its fanatical customer base, and this is not unconnected to the decades of work the enterprise has put into managing customer expectations and building the quality of its products to taste.

\subsection{Analysis of industrial and economic activity of the enterprise.}

The economic activities of the enterprise are analyzed using two recognized methods - the Porter's Five Forces model and the Strength, Weaknesses, Threats and Opportunities (SWOT) model.

The Porter's five forces analysis gives insight into the forces or factors that affect the success and long term. The five forces of competition, new entrants, suppliers, customers, and substitute products are analyzed in this study in relation to the CocaCola enterprise.

As established in the foregoing section, Coca-Cola towers high about its competitors, the most consequential of them being Pepsi. The activities of Pepsi and other competitors have been unable to dent the market influence of the Coca-Cola enterprise as it has continued cordon a gargantuan share of the market over the past years. This is entrenched by the loyal following the brand has amassed during its engagement in the beverage industry. Hence, the number of competitors lined up against the enterprise and their ability to cut into the market share and revenue volume of the Coca-Cola enterprise ranks moderate to low. The power of the enterprise as a market leader is entrenched and this positively affects its ability to charge higher prices and effect very favorable deals while cutting cost (otherwise spent on aggressive marketing campaigns) and maximizing profit margins.

Threats of new entrants. The non-alcoholic beverages market is a major player in the global beverages market, holding more than 50 percent share in the market - a trend that appears to have been on a steady upward trend but for the COVID-19 pandemic which saw the reduction in the level of consumption of soft drinks all over the world and the cancellation of major sporting events with capacity to boost the 
market growth in the past year. This connection of events resulted in a shrinkage of the global non-alcoholic beverages market from 900 billion USD in 2019, to 724 billion USD in 2020, these numbers are expected to spike to a record high 1.2 trillion USD by 2027 [46]. Although the market is attractive to new entrants who eye a chunk of the large global market, the market is highly consolidated in the grip of the current market players. The companies already active in the non-alcoholic beverage market have not rested on their oars but have continued to revolutionize their products in terms of quality and to meet consumer preferences and market trends (which continue to change with social, health and environmental considerations). It is in this line, that Coca-Cola, the chief market player has emphasized on releasing additions to fermented drinks, RTD beverages and VitaminWater range e.g., the Jaljeera drink, targeted at supplying the constant demand for energy drinks in India [47]. Additionally, a new brand will face an uphill task in replicating and matching the amount of brand recognition and customer loyalty the Coca-Cola enterprise already enjoys. The overawing dominance of the market leaders, the capital at their disposal and the willingness to twist and turn at the behest of the consumer creates a barrier against new entrants into the industry. With this barrier in place, the Coca-Cola enterprise maintains its power in the market and its profitability in the non-alcoholic beverage circles. This is because the in flock of new entrants will negatively impact the market power of the already established players, along with their profit margins.

Power of Suppliers. The power of the suppliers in the relation of the Coca-Cola enterprise will depend on the raw material in question. While resources for producing non-alcoholic beverages, such as, carbonated water, caffeine, sweetener, and phosphoric acid are available by a multitude of suppliers, acesulfame potassium is not readily available in viable quantity and quality from many suppliers. The Coca-Cola enterprise relies heavily on Nutrinova Nutrition Specialties \& Food Ingredients GmbH for the product [48].

Unlike Nutrinova, suppliers in the industry have a weaker bargaining power in terms of pricing against the market leader since the materials are available at cheaper prices. The number of suppliers is high, and it costs next to nothing for the enterprise 
to switch from one supplier to another, but the suppliers do not hold the same power. The suppliers are smaller and with less deeper pockets and as such, pulling the plug on the revenue generated from supplying an enterprise the size of Coca-Cola will significantly impact the profit margins of the supplier negatively [49].

Hence, the suppliers do not pose a significant threat to the enterprise and cannot escalate the price of inputs in a manner that will affect the enterprise significantly, due to the low switching cost for Coca-Cola vis-à-vis the higher risk of revenue loss for the supplier. This allows the enterprise to maintain control over its inputs and to maintain optimal profit margins.

Power of the Customers. Customers of Coca-Cola typically purchase in low volumes, scattered across various markets. However, the customer may switch loyalties between the enterprise and its key competitors at little or no cost at all, but then, the customers of Coca-Cola are not price sensitive since they always prefer the Coca-Cola brand to other brands [like Pepsi] despite the low differentiation between both brands. A retailer may however acquire more bargaining power, but this may only be because of the large volume of products it demands, this alone still does not allow the scales of power to tip heavily against the enterprise [49]. The inability of the retailer to tip the scale is significantly linked to the brand loyalty of the end users; this puts the retailer in a position where it must continue to carry on business with the enterprise on favorable terms to both, to continue to keep its lot from the large following and brand recognition already amassed by the enterprise.

Threat of Substitute Producers. Like the question of competition, the existence of Pepsi on the market as a viable alternative to Coca-Cola presents a significant problem. Pepsi can well serve as a substitute to the Coca-Cola brand as both products are not different from each other in many ways. The products offer similar [but different] flavors and tastes, making it plausible that one may be taken in place of the other at another time, except for cases where the consumers have developed a strong connection to the brand - which may not always be the case. The disparity in pricing between the two brands may also create a threat (moderate to high) to the Coca-Cola brand. 
Also, the existence of various energy drink, fruit juices and other hot or cold beverage brands may also create a substitute market against the traditional Coca-Cola brand. There is no doubting that the number of substitutes for Coca-Cola products is high and the switching cost for customers is typically low. However, despite the existence of viable substitutes and the potential they have, the fierce customer loyalty available to the Coca-Cola brand neutralizes the threats posed by the substitutes $[49, \mathrm{p}$. 6]. In summary, the five forces model indicates that the Coca-Cola enterprise experiences moderate threats from the competitors, while it is bound to encounter moderate or lower-level threats from all other forces - new entrants, suppliers, customers, and substitutes. (See Figure 5) This influence or lack of influence of these factors on the Coca-Cola enterprise illustrates the profitability of this enterprise and its suitability for investments.
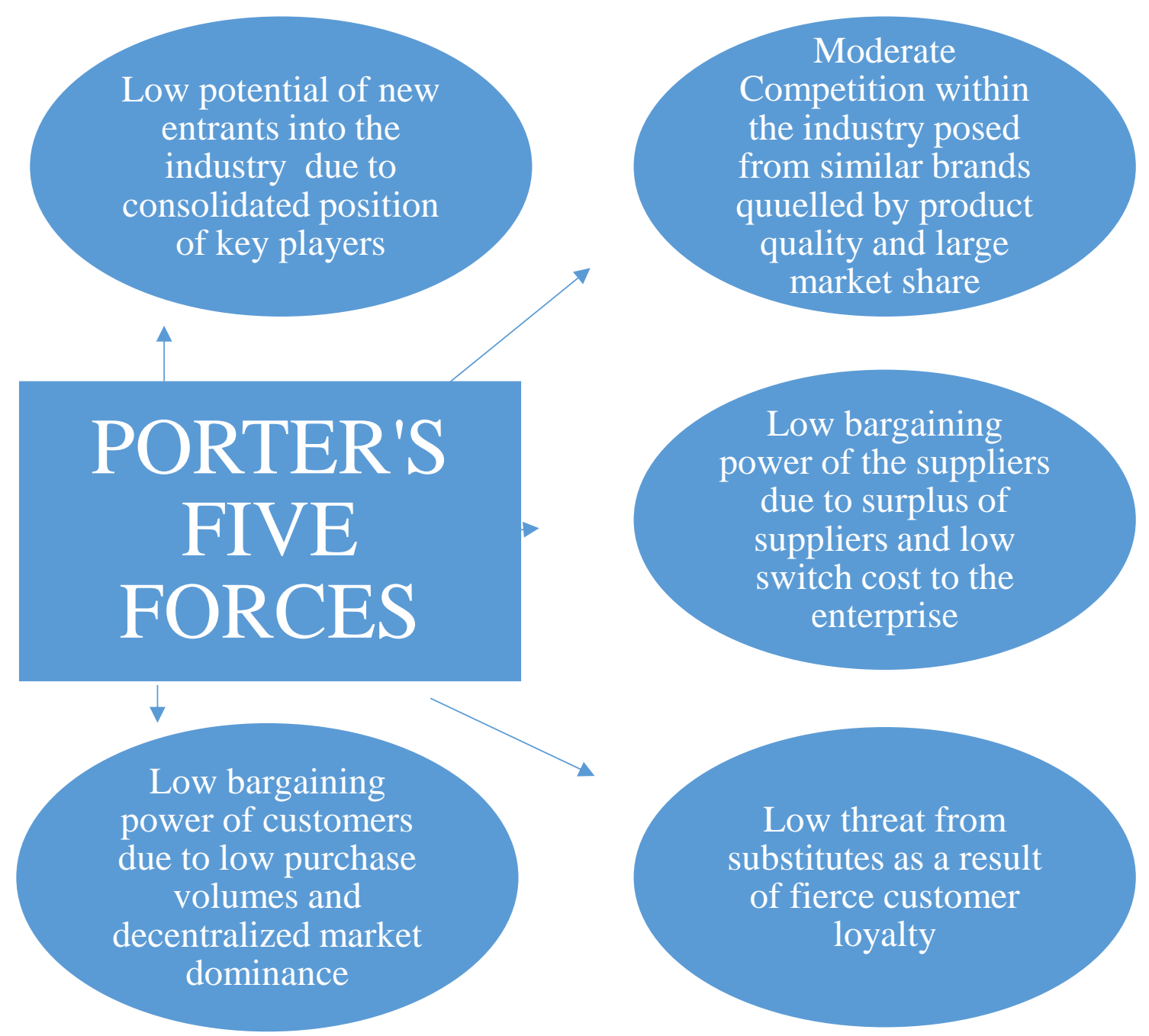

Figure 3: Porter's Five Forces analysis of the Coca-Cola Enterprise 
Using the SWOT analysis, the study will assess the internal and external factors, and current and future potential of the Coca-Cola enterprise. The analysis will rely on data from the enterprise within the last three years $(2018$ - 2020) and based on the analysis, we shall draw conclusions on the progress of the enterprise and any avenues available for improvement. Upon a proper analysis, potential investors into the enterprise are abreast with the economic activity of the enterprise and how this may affect the quality and safety of their investments, and if there are any risks, allows the investor set processes in place to hedge against them.

\section{a) Strengths:}

i. $\quad$ Strong Brand Value

The value of the Coca-Cola brand pegged at 87 billion USD, is sixth on the list of the best global brands in the world as of 2020 [50]. Its brand value places it ahead of its competitors. The enterprise sits as a market leader in the non-alcoholic beverage sector with a comfortable lead ahead of its competitors in terms of brand value [50]. The superior brand value of the enterprise is due in part to the exceptional and detailed advertisement strategy it has employed e.g., the use of personalized bottles which consumers shared over various social media, keeping the brand in the eye of the public all year round. To put the advertising effort of the enterprise in perspective, the enterprise doles out 2.8 billion USD globally. These and other factors contribute to the solid brand value of the enterprise.

\section{ii. Global Reach}

The Coca-Cola enterprise as leader of the non-alcoholic beverages market, has its tentacles spread abroad with 225 bottling partners and 900 bottling plants worldwide. From a small start-up beverage in Atlanta, within the course of over a century, Coca-Cola has transformed itself into one of the most recognizable brands in the world, extending into every region of the world and claiming a spot as a market leader in.

\section{iii. Revenue Growth}

Between the 2019 and the 2020 financial years, the enterprise increased net sales by 180.8 million USD and by the end of the second quarter of 2021, the net revenue of 
the enterprise was reported at 10.1 billion USD, attributed in part to the bursts of economical energy flowing from recovery oof nations from the COVID-19 pandemic [36]

\section{b) Weaknesses:}

i. $\quad$ Health Concerns:

There have been allegations against the enterprise concerning its role in deceiving the consumers about the health risks that arise from the consumption of the sugary beverages [51]. A nonprofit project had accused the enterprise alongside the American Beverage Association trade group in a lawsuit of downplaying the risks of obesity, diabetes, and cardiovascular disease because of consumption of sugary beverages. The nonprofit alleged that the defendants have despite scientific evidence to the contrary used euphemisms to mislead consumers on the effects of sugary beverages, to boost sales.

\section{ii. Environmental Concerns:}

The Coca-Cola brand has been labelled the world's most polluting brand [52]. An environmental audit conducted by 'Break Free from Plastic' adjudged the enterprise as a top offender in the sphere of environmental pollution. With over 72,541 volunteers across 51 countries and six continents, the audit encompassed drive to comb neighborhoods, beaches, waterways, and streets of plastic waste. Of 475,000 pieces of plastic waste collected, the majority were waste from Coca-Cola products. This comes at the backdrop of environmental activists describing the enterprise as constituting a climate, health, and social justice issue [53].

\section{c) Opportunities:}

i. Introduction of non-beverage items:

The enterprise can diversify its product range beyond beverages. This presents an opportunity for the enterprise to mitigate risks already associated with its involvement in a product-specific market such as the non-alcoholic beverage market. With its already concrete distribution network, Coca-Cola can extend into segments complementary to the beverage segment e.g., snacks; this will be at a relatively lesser cost given the dominance of the enterprise. 
ii. Innovation in Coca-Cola's supply chain:

The Coca-Cola supply chain processes 160,000 orders on a daily basis. The enterprise may boost efficiency in distribution using advanced technology, the adoption of blockchain technology in the supply and distribution infrastructure. With the use of cryptocurrencies, the enterprise can boost efficiency, effectiveness, and accountability throughout its networks.

iii. Added focus to the health drinks category

Considering the global posture towards healthy living - especially in the aftermath of the COVID-19 pandemic - the market for carbonated drinks may risk shrinking. This creates an opening for the enterprise to engage in the production and marketing of healthier alternatives e.g., bottled water, teas and coffees, shakes, and smoothies. This opens a window into the 478 billion USD global health drinks industry.

\begin{tabular}{|l|l|}
\hline \multicolumn{1}{|c|}{ Strengths } & \multicolumn{1}{c|}{ Weaknesses } \\
$\begin{array}{l}\text { 1. Strong brand value } \\
\text { 2. Wide global reach } \\
\text { 3. Revenue growth }\end{array}$ & $\begin{array}{l}\text { 1. Health concerns } \\
\text { 2. Environmental concerns }\end{array}$ \\
\hline \multicolumn{1}{|c|}{ Opportunities } & \multicolumn{1}{c|}{ Threats } \\
$\begin{array}{l}\text { 1. Introduction of non-beverage } \\
\text { items }\end{array}$ & $\begin{array}{l}\text { 1. Competition } \\
\text { 2. Innovation in Coca-Cola's supply } \\
\text { chain }\end{array}$ \\
$\begin{array}{l}\text { 3. Added focus to the health drinks } \\
\text { category }\end{array}$ & $\begin{array}{l}\text { COVID-19 } \\
\text { beverage as against carbonated } \\
\text { and sugary drinks }\end{array}$ \\
\hline
\end{tabular}

\section{Table 2: SWOT Analysis of the Coca-Cola Company}

d) Threats:

i. Competition:

The Coca-Cola brand faces direct competition from Pepsi, which is the lead contender from its sport as leader of the non-alcoholic beverage market, other brands 
like Red Bull, Starbucks, Monster Energy, etc. offer indirect competition. However, this competition within the industry spurs continuous innovation.

ii. Global Uncertainty due to COVID:

The COVID era heralded a steep decline in sales and consequentially, revenue for the market leaders. Even at the end of the pandemic, its impact still hovers and significantly affects profit margins in large markets like India [54].

iii. The demand for nutritious beverage as against the carbonated and sugary beverages:

Individuals the world over have continued to shift towards more nutritional choices in drinks and beverage. In the long term, the enterprise is bound to witness a decrease in sales of its core products - the carbonated drinks.

\subsection{Co-operation between the Coca-Cola Enterprise and the Service Industry.}

Following centuries of evolution, there has been a shift from the agricultural economy and then to the industrial economy. In the mid-twentieth century, the US heralded the transition towards a service economy $[79$, p. 1]. The service industry has since become indispensable in any economic set-up, growing at amazing speed throughout the world, and consisting of various industries such as the retail and wholesale, tourism, trade, entertainment, motion picture, information and communication technology, and education.

The service sector of various economies has been fingered as a predominant source of the gross domestic product and employment [80, p. 1]. However, the greatest advantage of the service industry is the effect it has on other sectors/industries within the economic setup. The service industry is the oil on the engine of the other industries, facilitating the operation of these other industries through banking services, information, and communication technology, etc.

In Ukraine, the most prominent aspects of the service sector are tourism and financial services; other developed aspects of the service sector in Ukraine are telecommunications services, banking services, legal services, audit, and accounting 
services, while services like engineering, insurance, private health care and security are considered underdeveloped [81].

Part of the manufacturing industry, the Coca-Cola enterprise depends on the service sector for its proper functionality even as it thrives towards innovative activity. The enterprise depends largely on the hospitality industry and (in its drive towards innovation) the information and communication technology industry.

In understanding the intercourse between the Coca-Cola enterprise and foreign investments in its drive towards innovation, two reports from the company were examined:

1. How Coca-Cola is rethinking disruptive innovation to anticipate tomorrow's tastes.

2. Streamlined portfolio of brands, marketing, and innovation to power Coke's 2021 strategy

From these reports, conclusions were drawn on the extent and character of innovative activity in the enterprise and the level to which these innovations were spurred [if at all they were] by foreign investments.

In a bid to meet the changing needs of the customer, the Coca-Cola company has been keen on innovations in various aspects of product content and composition, product design and strategy. The state of the innovative activity of the enterprise as derived from these reports led to the recognition of two core areas of innovation activity on which the enterprise has laid its focus.

First, the company revamped its technological and digital model in the wake of the pandemic to take advantage of the opportunities created by the lockdowns and heavy reliance on digital technology within that period. The pandemic despite its ills, sped up the transformation of the enterprise into a 'digitized, data-driven organization that can execute marketing, commercial, sales and distribution strategies in both online and offline worlds'. The innovations in the digital aspects of the enterprise have had influences on the processes and results of the enterprise. These are observed in the following:

a) Transformation of logistics 
b) Transformation of the entire distribution model

c) Transformation of client relationships

d) Transformation of the methods of consumer-enterprise interaction

The execution of this digital drive is the Sprite, 'Let's Be Clear' campaign, the enterprise embarked on the creative use of digital advertisements over print, television, and social media [55].

Second, the enterprise is tapping into consumer preferences by breaking into emerging categories - Kombuchas, cultured ciders, keto-friendly smoothies, and coldbrew coffees. In the endeavor, the enterprise has deployed a team of specialists who will peer into uncharted territory, a challenge existing approaches to innovation using an agile as well as a test-and-learn model. The specialists cut across Research and Development (R\&D), Quality, Safety and Environmental Sustainability, Technical Commercialization, and Scientific and Regulatory Affairs (SRA). In building these cutting-edge innovations in taste and quality of the enterprises' products, the enterprise leverages its financial capabilities and the talent in its workforce to push its advantage into new and emerging segments [56].

For example, the Coca-Cola with Coffee - Coca-Cola infused with Brazilian coffee - was launched in North American markets from January 2021 in three flavors - Dark Blend, Vanilla and Caramel; the drink which comes with a zero-sugar variant, is a ready-to-drink brand and marks an inroad of the beverage leader into the coffee market. This innovation follows the launch of Coca-Cola energy products - Coke Energy/Coke Energy Cherry in United States markets and it heralds the immersing of the brand in other uncharted territory, hence, increasing the revenue of the brand while creating a chance at customer-base enlargement.

At the core of the activities in any enterprise is capital. This capital may be derived from a variety of sources, but this research study is keen on the role foreign investments play in filling the gaps of innovation in any enterprise [57, p. 1]. For the more mature enterprises, the financing needs are less problematic than it is for medium and small enterprise which seek to finance innovation activity. 
Governments have played a role in financing innovation activity through the implementation of tax incentives and public loan guarantees with respect to innovation activities, and through public funding for R\&D activities.

An examination of the reports of the enterprise revealed that the bulk of the innovative activity of the enterprise is funded from within - its revenue. Foreign investments in an enterprise may be with its ills as well as its advantages, however, the rest of this study will be devoted to a qualitative study of the possible impact of innovative activity on the Coca-Cola enterprise from which the study shall fashion out suitable methods to boosting the inflow of foreign investment into the enterprise to spur investment. 


\section{CHAPTER 3 \\ FINDINGS AND RECOMMENDATIONS}

\subsection{Recommended mechanisms for attracting foreign investment for innovative activity in the Coca-Cola enterprise.}

The impact of foreign investment on innovative activity is beyond reproach. The focus of this study is on the mechanisms and strategies that may be employed by an enterprise to boost its inflow of foreign investment. To be able to fully appreciate the aim sought to be achieved in this chapter, the study takes a foray into the importance of foreign investment in an organization. However, there is a dearth of literature on the specific subject oof foreign investment in innovative activity of corporations (which is what this study focuses on). This research is qualitative research; hence the research will take advantage of already established knowledge in the field, from which conclusions will be drawn and recommendations will be made affecting the subject of the research study. Other recommendations will be made concerning the improvement of economic activity in the enterprise as well as recommendations for the management of the company.

As stated, most discourse on foreign investment is focused on countries rather than commercial corporations, this leads to a paucity of research on the topic. That end, this study relies on research and studies about foreign investment and innovation in countries. Bearing the mind, the similarities and dissimilarities between countries and corporations, the study will extrapolate and from thence, make recommendations.

Erdal and Gober make elaborate arguments on the effect of foreign direct investment (the more popular form of foreign investment) on innovations [58, p. 750]. Upon an understanding of the impact of foreign investment on innovative activity, the study delves into the crafting of proper strategies. In this respect, MGaleevaa and Kadeeva, highlight the problems experiences in the drive to attract foreign investment to an endeavor [59, p. 7] and this is supported by the research of Donciu, who attempts to devise methods through which countries may promote and attract foreign investment [60, p. 23]. 


\subsubsection{Effect of Foreign Investment on Innovation, and Research and Development}

Foreign investment is a larger concept than the mere deposit of financial capital. It extends to the transfer of technological knowledge and management expertise and has been credited for spurring growth in countries like India, China, and Malaysia. This study by Erdal and Gober attempted an investigation of the effect of foreign investment on research and development, and innovation in the following countries:
a) China
b) South Korea
c) India
d) Iran
e) Pakistan
f) Malaysia
g) Singapore
h) Thailand
i) Saudi Arabia
j) Turkey

In reaching its conclusions, this study took into consideration the $R \& D$ expenditures, the number of patent applications (from domestic and foreign sources), and the capital stock by the foreign direct investment for the period between 1996 and 2013 (the study period). Using these set of data, the following conclusions were arrived at:

i) Foreign direct investments were by far the easiest way to bridge the capital deficit in developing countries, bringing the advancements in these countries fairly to the level of their more developed counterparts. Through these investments, there is not just movement of financial capital, but transfer of machinery (factory and equipment), and expertise.

ii) The inflow of foreign direct investments to these developing countries has been the core component of economic development in these countries; the growth occurred through the investments in $R \& D$ which sped up the pace of 
high technological development and the R\&D stock of the host countries. These developments lead to the production of new products, enhanced versions of the old products and formulation of new production processes innovation and innovative activity - in the host country.

iii) To boost capital and to make up for deficiencies in technology, countries that lack in these respects must develop strategies to attract more foreign direct investment. And in attracting these investments, the investors must be availed the benefits of tax incentives, property rights and cost benefits.

1.1.2. Problems of attracting foreign direct investment into the regional economy

This study by MGaleeva and Kadeeva $\mathrm{x}$-rayed the entire concept of foreign investment to draw out the common problems associated with attracting foreign direct investment to an economy. In this study, Russia is used as a case study of the circumstances and factors affecting the inflow of foreign direct investment into an economy. At the conclusion of this study, the authors proffered possible solutions to these problems highlighted. According to the study, the principal factors affecting the attraction of foreign direct investment to an enterprise are access to markets and resources. In Russia - the subject of this research study - the decrease in the inflow of foreign direct investment is traced to the political risks attendant in the country. Apart from the semi-dictatorial nature of the state (although avowed to be democratic in theory), the sanctions levelled by the United States and the international community (mostly the Western Bloc) create unpredictability and investments are not likely to attain optimal reward under these situations.

Following the imposition of sanctions on the Russian Federation in 2014, the inflow of foreign direct investments declined by over $300 \%$ by 2015, from the range of 22 billion USD to around 4.8 billion USD - the least figure recorded for foreign investments in the country since 2002 . The pattern of investments by the foreign investors shows clear preference for areas where innovative activity was more pronounced: wholesale and retail trade, manufacturing, finance and insurance, and mining. 
An analysis of this study elucidates factors affecting the inflow of foreign investment into a country as follows:

a. Access to markets and resources

b. Economic and political stability of the country. In this light, the existence of stringent sanctions a country has a direct impact on the quality of the quality of its foreign investments.

\subsubsection{Promoting and attracting foreign direct investment}

In the study, Donciu acknowledges, like other authors in this section, the overwhelming importance of foreign investment to host nations and goes many steps further into recommending methods for attracting and promoting foreign direct investment in an economy.

Government policy plays a key role in the suitability of a country for investment, in this vein, the three generations of policies to promote foreign investment come to play. The first generation emphasizes the formulation of policies friendly to the investor. In achieving these policies, the government may take an adverse posture towards barriers to investment inflow by removing any appearances of discrimination in the treatment of foreign investors. This approach may work well in less-developed countries so far as the necessary economic determinants to achievement of foreign investment are intact.

The second generation on the other hand, involves the attempt of the host government to attract foreign investment by the persistent representation of the state as a destination for investors and their investments. In executing this approach to policymaking, the states embraced the establishment of national investment promotion agencies - with the primary aim of executing programmes abroad to promote investments in the home country.

The third generation, however, is founded on the assumption that the preceding generations are only a start for the approach which foreign investors will follow at the industry and firm level to meet their needs while bearing in mind the priority of the host country in the investment endeavor - development. The effectiveness of this strategy is profound in regions where there are clusters based on competitive 
advantages, exploiting the tendency for firms to cluster in a territory which may subsequently acquire an established brand. It must be noted that the arrival at the stage where there is an 'established brand' is not automatic. It takes considerable time and efforts in terms of cost and will depend largely by the institutional capacities. This third-generation approach is popular as can be seen in the prevalence of export promotion agencies at regional and municipal levels.

At the conclusion of this research, the following levers were highlighted as key in promoting research in any country:

a) Policies aimed at ensuring access to foreign market;

b) Policies aimed at improving access to imported inputs;

c) Provide commercial facilities;

d) Export performance requirements;

e) Use incentives.

\subsubsection{Findings and recommendations}

Considering the totality of the research about foreign investment for innovative activity, foreign investment is key in the drive to enhance innovative activities in any enterprise. Although the research studies relied on are tilted in the direction of nation states, the principles expounded in the studies will apply in like manner (with only slight variations) to commercial enterprises like Coca-Cola.

Like governments, businesses are established for a purpose although unlike governments which are service-oriented, businesses are created for the purpose of profit [Gupta, 2008]. The policies of any business organization or enterprise are geared towards the actualization of that goal; and in pursuit of that goal, comes the need to remain competitive in the markets. At the core of competitiveness, is innovative activity. The following mechanisms are recommended as viable to promote foreign investment in the innovative activity of the enterprise.

1. Policy

2. Investment promotion arm

\section{Policy}


In the discourse of foreign investment in countries, the question of policy was observed to be vital if at all investors will be keen exploring the potential for success in the host country. The same holds for enterprises. The core purpose of investments to get value - financial value. Any person or organization devoting money to a business venture does so in the expectation that certain agreed benefit, having considered the risks involved, will accrue to the investor upon the maturation of the investment or anytime so soon thereafter.

To this end, the enterprise must operate policies that are friendly to potential investors; its policies must demonstrate to the potential investor the strong likelihood that at the appointed time, the investment made in the innovations of the enterprise will bear good fruit. An instance is the introduction of the health drinks category given the increased consciousness of consumers about the health implications for sugary drinks. With this, the enterprise demonstrates its willingness to embrace policies that shine a positive light on the attitude of the enterprise to concerns raised about the health implications of its business. It will be foolhardy for a business intent on making profit, to ignore the needs of the customers. The investor is more comfortable with the investments in the innovations as they are directed in the direction where the consumer is headed; and this has the potential to break into customer bases which were not typically open to the enterprise.

\subsection{Investment Promotion Arm}

Companies by virtue of their size, financial capacities, and reach, have the semblance of governments but for their primary motive which is to draw profit rather than the mere offering of services. The core aim of a private enterprise [although exceptions abound] is to make profit. Although the enterprise may from time to time engage in some altruistic or non-profit affair, either as part of its corporate social responsibility or on any other basis, it does not derogate from the primary purpose for which the enterprises are floated. 
To this end, the enterprise may designate a section with the sole responsibility of promoting the innovative activities already undertaken by the enterprise. Overtime, these agencies have been effective in attracting foreign investments to countries (this does not discount the fact that the effectiveness of the agency may depend on the investment climate and the level of development of the country) [61, p. 55]. The same can be replicated in business enterprises. This arm must be manned by persons sufficiently versed in the activities of the enterprise; and guided by the SWOT analysis of the enterprise, they must bring to light the strengths of the enterprise and strategies in place to remedy its weaknesses and hedge against potential threats. The presentations must also reveal the opportunities available to the enterprise, the potential it brings, and the strategies put in place to take advantage of these opportunities within specific time frame.

The Coca-Cola enterprise may utilize this strategy by exposing its target investors to the innovative inroads made by the company in areas such as coffee, energy drinks and other non-carbonated drink categories. Given the vast potential available in that sub-market, and placing it side by side by the already solid name and brand of the enterprise, investments into further innovations will flourish.

\subsection{Recommendations for improvement of economic activity at Coca- Cola}

The Coca-Cola enterprise has been known for over a century for its brand of carbonated drinks and this has been a consistent focus of the brand as it is a market leader in the non-alcoholic beverage industry. Despite its clear dominance over its competitors, the enterprise faces the unfortunate risk of declining market share. These risks flow from:

a) Health concerns over the long-term effects of carbonated and sugary drinks; and

b) Negative publicity arising from the allegations that the enterprise is complicit in environmental pollution resulting from the use of Coca-Cola products. 
Also, blockchain technology should be incorporated into the business model of the enterprise.

\section{a) Health Concerns:}

The soft-drink segment of the beverage market bears the tag of a harbinger of ill-health as many reliable sources have credited it as responsible for an 'obesity pandemic' among other health challenges that pervade people in this age.

Vartanian, et al., in a study titled "Effect of soft drink consumption on nutrition and health: A systematic review and meta-analysis", investigated the linkage between the consumption of carbonated drinks and nutrition and health outcomes. This study sought to address that concern over the association between soft drink consumption and increase in body weight and energy intake. In attempting this study, the authors focused on research investigating the effects of sugar-sweetened beverages. The study observed that there was a clear correlation between soft drink consumption and increased energy intake. This intake of energy had an adverse effect on the health of the individual; offering energy with little nutritional value, the energy from the drinks displaces the other nutrient sources, creating the potential for medical conditions such as diabetes. On this basis, it was recommended that persons cut down on the consumption of soft drinks. These warnings on the potential harm resultant from the consumption of soft drinks is exacerbated by the global health catastrophe occasioned by the covid-19 pandemic.

To maintain profitability in the long term, it is important that the enterprise can rid itself of that, if not entirely, then gradually. Rather than in engage in any public relations scrimmage - as is characteristic of most large corporations, with deep pockets and gallant legal, publicity and crisis management teams - it is in the interest of the enterprise that it diversifies its product base to include health drinks and other beverages with nutritional value.

\section{b) Environmental Concerns}

In a 2019 report by The Independent, Coca-Cola was named the worst polluter in the world. This came hot on the heel of a similar report in the preceding year [Independent, 2019]. In the same way, many climate advocates have called for an end 
to the use of plastics in the production of Coca-Cola products [53]. In their arguments, the advocates have pointed to the role of improperly disposed plastics in feeding climate change.

The Coca-Cola enterprise is a prime user of plastics; hence it is no mean mistake that its name and corporate image is consistently called out whenever issues of largescale environmental pollution come up. Although it is convenient to suggest that the company is not itself responsible for the pollution of wildlife habitats, neighborhoods, and waterways with plastic packages of Coca-Cola products, this argument has proven to be to no avail. It is suggested that the enterprise owes a [indirect] duty to reduce to the barest minimum, the creation of circumstances where packaging of its products can be used to cause environmental harm. To do this, the enterprise must strive to eliminate the use of plastics in packaging its products.

It is recommended that the enterprise play a frontline role in the struggle to preserve the environment. It may consider a possible switch to tin cans as against the conventional plastic cans. Tin cans are better alternatives because they are lighter and are not made of fossils like their plastic counterparts and as such, they present less trouble to the environment unlike the process of making plastic cans which contribute significantly to environmental issues like acid rain and oxygen-free zones in the ocean [62].

\section{c) Incorporation of Blockchain Technology}

The production and sale of food and beverage, especially on a global scale presents a variety myriad of issues creating the need for modern solutions to attend to cater to these problems. A Siemens research study examined the utility of blockchain technology in the food and beverage industry [63]. These gargantuan industries are faced with issues.

First, the study records than one in ten consumers are victims of food-borne diseases, which result in over 400,000 deaths yearly. These are typically results of faults in the production process or activities of counterfeiters. Either way, the manufacturer and the consumers are made to bear the brunt of these unfortunate occurrences through recall of good and damage to the business image of the 
manufacturer (which many times are not quantifiable in monetary terms), and longterm health damage or death of the consumer [63, p. 3].

Secondly, bad experiences of the consumer largely affect the chances that the consumer will patronize or recommend the brand after such experience has occurred. This is exacerbated by the prevalence of social media from which details of sordid customer experience can be broadcasted by the click of a button. Customers post their bad customer experiences in social media at least 45 percent of the time. These reviews shape the opinion of consumers over the internet on the suitability of these products to meet their needs and not to cause them harm. Hence, the reviews or opinions about a product over the internet would actively shape consumer attitude towards that product [63, p. 3].

Thirdly, the spate of counterfeiting continues to mount at an alarming pace. These activities ranging from relabeling of expired products for onward resale as the genuine products to the representation of conventional beverage products as organic, etc., create massive profit centers for the perpetrators, mounting impetus and decreasing the likelihood that these activities will be abated even considering the harmful effects. Even though the manufacturer has no share in the blame for the existence of these products, the manufacturers bear the damage occasioned by these nefarious activities. Revenue loss running into billion of dollars yearly and the significant brand damage occasioned by these counterfeiting endeavors creates the need for lasting solutions to the problem [63, p. 3].

The study recommended blockchain as a solution to the issues identified. Admittedly, a large section of the public believes the term to be synonymous to cryptocurrency. However, cryptocurrencies for only a substratum of the concept of blockchain. Blockchain refers to a "special form of distributed ledger technology (DLT), a digital logbook for transactions that are combined into a block and chained together in chronological order - hence the name". In this technological interface, information and transactions are confirmed by all the participants through consensus algorithm. With these features, businesses and organizations can analyze large volumes of data efficiently. 
The study demonstrated the practical aspects of the use of blockchain technology in beverages. An instance was the Northern Irish craft beer manufacturer which uses the technology to inform consumers of all they needed to know of the drinks they consumed - ranging from the ingredients to the brewing processes. By scanning QR codes on the body of the product or visiting the manufacturers website, the consumers are taken into the minutest detail of the ingredients and processes through which the product was made.

The problems identified are common in the beverage industry given the close connection between the products and the health of the consumers. Apart from the already established correlation between health risks and the consumption of sugary beverages, the risk of direct harm [to the consumer and the company] from food scandals and the activities of counterfeiters. The Coca-Cola company may consider the adoption of these technological tools - QR codes, tracing software, Point-of-Sales systems - not only for their capabilities of stemming the tide of harmful practices of counterfeiters, but to also put the consumer at the center of the production activities, building trust in the brand while striving to extend the brand reach beyond its now seemingly inelastic limit.

\subsection{Recommendations for the management of the company}

The endgame of innovative activity is to enhance the competitiveness of the enterprise. Although this goal is achievable, there is no end to the drive for competitiveness. Hence, the enterprise must continue to evolve. It must seek out methods to improve its standing against that of its competitors, rather than rest on its oars as complacency may well lead to a decline in the gargantuan market share that the enterprise has amassed. The following recommendation is apt for the management processes of the enterprise:

The enterprise must take advantage of digital technology in its race towards competitiveness and full innovative capacity. Social media and POS systems by businesses have made great impact geared towards greater business profitability (even in the height of the pandemic), reducing overstocking to the barest minimum or 
eliminating it, etc. These potential benefits of social media and POS systems on the enterprise's communication with customers and prospects are as follows:

\section{a. Crowdsourcing:}

Crowdsourcing allows the enterprise to spread certain functions once performed by employees across a broader and undefined group of people [in this case, customers], in the form of an open call [64, p. 5]. With social platforms, the enterprise can crowdsource ideas by engaging customers and prospects on issues relating to intended products, that way the products rolled out by the company fit the needs of the market. This has been a trusted method of exploiting collective wisdom cost-effectively. Also, through crowdsourcing, the brands typically convert their customers into die-hard advocates [65]. This is particularly important given that consumers are likely to patronize a brand recommended by their family and friends [65]. Social media channels are most effective in carrying out the function of crowdsourcing and that could be through a variety of methods - surveys, polls, contests, etc. Through these methods, the company will be better positioned for effective business better decision-making by taking advantage of firsthand information from the consumer - who may or may not be a customer of the enterprise [66, p. 2].

\section{b. Competition:}

Businesses need to keep an eye on the competition for a variety of reasons the need to understand the standing of the company against its competitors, the need to identify the platform where the contents of the outfit perform best, gauge the manner and the extent to which the audience [a pool which comprises even of customers and prospective customers] interacts with the competition, and also glean into how the competition engages the audience [67]. The business may then attempt tailoring their marketing strategies to take advantage of the weaknesses of the competition while managing the effects of their strengths [68].

\section{c. Direct line to the current and prospective customers:}


Businesses cultivate customers using social media so much so that brands with solid social media followings have a direct connection with the consumers. The customers easily convey their complaints, criticisms, commendations, and opinions to the business; the business may then build its strategy around the perceived needs of the customer [69]. However, to take advantage of this benefit, the business must manage its social media properly [70]. Given the existence of this direct line, the customer may refer complaints directly to the business through social media - effectively preventing the damage likely to be wrought to the reputation of the company is the customers were without direct line and rather opted to share their [71]. Research shows that when a customer's complaints are handled, the customer becomes willing to patronize the business more in the future - this is more so when the complaints are responded to quickly [72].

Given the seeming stagnant customer base of the Coca-Cola company, a proper combination of social media and Point-of-Sale systems creates a mechanism that will revolutionize the approach of the enterprise to fathoming customer needs and marketing. With this in place, the enterprise is bound to increase its customer base which will lead to a necessary increase in its share of the market. 


\section{CHAPTER 4}

\section{LABOUR PROTECTION AND SAFETY IN EMERGENCIES}

\subsection{Occupation Health in the Workplace}

Like in any other industry involving the use of complicated machinery and technology manned by semi-skilled workers in the manufacturing of goods in large amounts, the beverage industry is not without its own set of hazard factors from which the employees must be adequately protected. Jobs commonly undertaken in the soft drink industry include packaging and machine operators, fork-lift operators, as well as mechanic and manual operators. Most operators on the jobs receive little or no formal training and most times will learn the rudiments of the job they are employed to undertake in the course of that employment.

In studying the occupational risks attendant in the beverage industry (to which Coca-Cola belongs), this study relies on the International Labor Organization's Encyclopedia of Occupational Health and Safety. The encyclopedia deeply studies the industry and from this study, recommendations are drawn for proper safety at the work.

In soft drink production, which has become highly automated in recent times, the steps engaged to birth the finish product are as follows [73]:

a) Water treatment

b) Compounding ingredients

c) Carbonation

d) Filling

e) Packaging

The above processes are highly automated, significantly reducing the risks of liftingrelated injuries, since rather than bear the heavy products, employees are trained to man machinery which would always do the lifting. Hence, most of the work-related stress is effectively transferred to the pieces of equipment. But the superb level of automation does not all together do away with the risks attendant in the beverage manufacturing industry. The plant and machinery used in the pre-production, production and packaging stages are themselves, sources of risk to the employees. To put this assertion in perspective, high-speed equipment such as fillers and conveyors 
may result in severe injuries by snagging the clothing and body parts of an employee, if improperly manned. The risk is multiplied in the case of overhead conveyors, which may fall and cause grave injury even to employees not involved in manning the machinery.

Additionally, the filling rooms are susceptible to wet conditions, and this poses the risk of slip-and-fall incidents which may occasion injury levels ranking from unserious to grievous. Even worse is the risk of electrocution because of the use of high-power electric machinery in these conditions.

Chemicals in beverage manufacturing and packaging facilities are mostly less hazardous - although they may not be ideal for consumption. However, the operations in these facilities juggle a great deal of highly flammable substances, acids, caustics, and corrosives, creating significant risk of bodily injury to employees who encounter the materials and worse, fire incidents.

From the foregoing, it is revealed that even during mass automation of the work environment where beverages are produced and packaged, there is till risk of significant injury resulting from the use and operation of and contact with the equipment. These necessitate government regulation of the work environment.

\subsection{Emergency plan at the workplace}

The State labor service reported 4,126 work-related accidents in 2018, 409 of which were fatal. This had been partly due to circumstances beyond control, but most times, they were simply a result of the unwillingness of the employers to abide by norms regulating employee safety and occupational health. To guard against these occupational hazards at the workplace, the Ukrainian government has developed as framework of municipal and international regulations to guide the safety of employees in the workplace [74, p. 15]:

a) The Constitution of Ukraine national policy on occupational safety in Article 43, require that employers provide proper, safe, and healthy working conditions to prevent occupational accidents and diseases. 
b) The State National Programme on Improving Safety, Occupational Health, and the Working Environment for the period of 2014 - 2018 was formulated and adopted to provide comprehensive approaches to labor protection, to ensure that workers are provided with safe and healthy workplace environments, minimizing risk of injury and accidents on the job.

c) On the international front, the state operates 71 ILO conventions that directly or indirectly cover issues relating to occupational safety and health. These include the radiation Protection Convention, 1960 (No. 115); the Hygiene (Commerce and Offices) Convention, 1964 (No. 120); the Occupational Cancer Convention, 1974 (No. 139); the Occupational Health Services Convention, 1985 (No.161); the Major Industrial Accidents Convention, 1993 (No. 174), etc.

The totality of these rules, laws, policy documents and conventions, demonstrate a devotion to the occupational health of the employees. In special relation to employees of beverage manufacturing plants and factories, the following safety measures are necessary:

1. Equipment capable to causing damage or injury upon contact (conveyors, pulleys, gears, spindles) must be provided with covers to prevent contact and possible injury.

2. Overhead conveyors have a risk [although low] of falling. To eliminate the possibility that this event will lead to injury, the factories must have netting or wire-mesh screens to protect against falling.

3. To prevent injury caused by wet floors in the filling rooms, the rooms must be equipped with proper drainages; work footwears must be fitted with slip resistant soles; and electric equipment must be guarded with insulators to eliminate the risk of electrocution.

4. Employees of the enterprise must be adequately taught on the methods storing, handling disposing of the chemicals; also, they must go through theoretical and practical sessions on how to use protective gear properly. 
5. The enterprise must provide eyewash stations and showers to minimize injury from possible exposure to harmful chemicals used in the manufacturing of beverages.

6. New employees must be subjected to compulsory training on safety and protection in the workplace; these trainings may also take place periodically to entrench a culture of safety in the workplace. 


\section{CONCLUSIONS}

At the core of the essence of any enterprise is the need to remain competitive. To build competitiveness, an enterprise must resort to a variety of methods. However, the focus of this study is the role of foreign investment in enhancing the innovative capacity of an enterprise and the strategies through which the enterprise may attract foreign investments.

During this study, it was established that innovativeness is an important factor in the drive for competitiveness among enterprises. This innovativeness is spurred by the extent to which the firm engages in innovative activity. This may be affected by a variety of issues like the size of the firm, the degree of state support for the enterprise and the available fiscal policies. Certain factors such as risks, high cost, and the longterm of expected return, are possible threats to the development of innovative activities in an enterprise.

Foreign investment on the other hand, may be direct or indirect. This study paid primary attention to direct investments - as they are the more conventional methods utilized. However, in the study on foreign investments, it was discovered that foreign direct investment is mostly directed towards countries as against corporate bodies who would mostly fund their innovative activities from internal sources.

In attempting the study, a qualitative approach was utilized. The research featured information detailing the impact of foreign investment on innovative activity, the methods of attractive foreign investment and the factors that are more likely to hinder foreign investment. From the information gathered and upon a proper analysis of the subject of the research (Coca-Cola), conclusions were reached on the ideal methods for attracting foreign investment in the enterprise.

The study engaged in a thorough study of the Coca-Cola enterprise. This study pervaded areas such as the historical development of the enterprise, its leadership and management, its financial standing and assets, its competitors, and the level of competition in the industry. Using the Porter's five forces, the study analyzed the enterprise to uncover its standing against the five factors and its overall strength and suitability for investment. The enterprise was also analyzed using the SWOT model, 
detailing the strengths, weaknesses, opportunities, and weaknesses of the enterprise. In digging into the innovative activities of the enterprise, it was discovered that CocaCola was keen on innovation, and this was witnessed in its technological and digital segments, and then, it had made significant adjustments to its product categories to include beverage choices that fit into the needs of customers e.g., Smoothies, cultured ciders, and coffees, etc. But as mentioned earlier, the key source of capital for innovation is the revenue and capital assets of the enterprise.

In the chapter that followed, the study used the qualitative methods to develop strategies for attracting foreign investment in the enterprise. The strategies arrived at were the development of investor-friendly policies and the establishment of an investment promotion arm for the enterprise. Recommendations were also made towards the improvement of economic activity in the enterprise.

The concluding, the study took on a discourse on the issue of labor protection and safety in the event of emergencies. In this discourse, the study examined the situations necessitating protection in the workplace, and the legislative steps taken by the state to ensure the protection of workers in any enterprise. The study ended with recommendations for the safety of the employee within the workplace.

At the end of the study, the student has been able to decipher methods through which foreign investment could be attracted to Coca-Cola enterprise as well as distinct methods of building economic progress in the enterprise. 


\section{References}

3. Clarysse, B., Wright, M., Bruneel, J., \& Mahajan, A. (2014). Creating value in ecosystems: Crossing the chasm between knowledge and business ecosystems. Research Policy, 43(7), 1164-1176.

4. Dimnwobi, S, Ekesiobi, C, Mgbemena, E. Creativity, Innovation and Competitiveness in Nigeria: An Economic Exploration. Creativity, Innovation and Competitiveness in Nigeria: An Economic Exploration. International Journal of Academic Research in Economics and Management Sciences 2016, Vol. 5, No. 3 ISSN: 2226-3624 [Online] Available from: https://hrmars.com/papers submitted/2242/Creativity, Innovation and Competitiveness in Nigeria An Economic Exploration.pdf (Accessed: 6 October 2021)

5. Sharopovna, I. Factors that determine the innovative activity of enterprises. International Journal of Research 2019, Vol. 6, No. 2 e. ISSN: 2348-6848 [Online] Available from: https://journals.pen2print.org/index.php/iir/article/view/16983/16566 (Accessed: 5 October, 2021)

6. Arefieva, O, Piletska, S. The innovative activity of enterprises as a prerequisite for sustainable economic development. Baltic Journal of Economic Studies 2018, Vol, 4, No.1. [Online] Available from: http://www.baltijapublishing.lv/index.php/issue/article/view/325/pdf (Accessed: 6 October 2021)

7. OECD/Eurostat (2005), Oslo Manual, Guidelines for Collecting and Interpreting Innovation Data, Paris: OECD

8. Resler, M. V, Zozuliak, M. M, Shygun, M. M, Ostapiuk, N. A, \& Zayachkivska, O. V. Evaluation of innovation activity of enterprises in Ukraine. Revista 2019, Vol, 40, No. 34. ISSN: 07981015 [Online] Available from: $\quad$ https://www.revistaespacios.com/a19v40n34/a19v40n34p20.pdf (Accessed: 6 October, 2021) 
9. Sivalogathasan, $\mathrm{A} \& \mathrm{Wu}, \mathrm{X}$. The effect of foreign direct investments on innovation in South Asian Emerging Markets. Global Business and Organizational Excellence 2014, Vol. 33, No. 3. [Online] Available from: https://onlinelibrary.wiley.com/doi/full/10.1002/joe.21544 (Accessed: 6 October 2021)

10.Aydalot, P \& Keeble, D. High technology industry and innovative environments: The European Experience. Routledge 2018

11.Akhmetshin, E.M., Vasilev, V.L., Mironov, D.S., Yumashev, A.V., Puryaev, A.S., \& Lvov, V.V. Innovation process and control function in management. European Research Studies Journal2018, 21(1), 663-674

12.Prigogine, A.I. Innovations: Incentives and obstacles (social problems of innovation). Moscow, Politizdat 1989

13.Goncharenko, I., Sybachin, S., Rakhimova, S. \& Podbiralina, G. Innovative activity of enterprises in the digital economy. IOP Conference Series: Earth and Environmental Science 33, 2019 [Online] Available from: pdf (iop.org) (Accessed: 6 October, 2021)

14. Chandy, R. K., \& Tellis, G. J. The incumbent's curse? Incumbency, size, and radical product innovation. Journal of Marketing, vol. 64, No. 3, 2000, p. 117

15. Dean, T. J, Brown, R. L \& Bamford, C. E. Differences in large and small firm responses to environmental context: strategic implications from a comparative analysis of business formations. Strategic Management Journal, vol. 19, No. 8, p. $709-728$

16.Cohen, W. M \& Klepper, S. A reprise of size and R\&D. The Economic Journal, vol. 106, 1996. No. 437, p. 925-951

17. Ferencz, V \& Dugas, J. Management of Innovation. Brussels: Euroscientia, 2012

18. Balabanov, I.T. Innovatsionnyi menedzhment [Innovative management]. Saint Petersburg: Piter, 2000 
19.Karagianni, V., Papagrigoriou, A., Kalantonis, P., Chalikias, M. \& Drosos. Entrepreneurship and innovation: Current aspects. Tourism, Culture, and Heritage in a Smart Economy, 2017

20.Endovitskii, D.A. \& Gilyarovskaya, L.T. Investitsionnyi analiz v realnom sektore ekonomiki [Investment analysis in the real economic sector]. Moscow: Finansy i statistika, 2003

21.Camison-Zornoza, C, Lapiedra-Alcami, R., Segarra-Cipres, M. \& BoronatNavarro, M. A meta-analysis of innovation and organizational size. Organization Studies 2004, vol. 25, No. 3, p. 331-361

22.Love, J. H. \& Ashcroft, B. Market versus corporate structure in plant-level innovation performance. Small Business Economics, 1999, Vol. 13, No. 2, p. $97-109$

23.Bruothova, M., Hliboka, L., Hintosova, B. A. Innovation activity and enterprises size. Central European Journal of Management 2014, Vol 1, No. 1, p. 5 - 11 [Online] Available from: (PDF) Innovation activity and enterprises' size (researchgate.net) (Accessed: 6 October 2021)

24.Moritz, E. B. 20 Years Inside the Mind of A CEO...What's Next? 20th Survey of CEOs of the World's Largest Companies, PwC, (CEOSurvey PwC) [Online] Available from: https://www.pwc.com/ig/en/ (Accessed: 6 October 2021)

25.Chen, J. Foreign Investment. Investopedia 2020, [Online] Available from: https://www.investopedia.com/terms/f/foreign-investment.asp

(Accessed: 6 October, 2021)

26.Meyer, K. E., \& Sinani, E. When and where does foreign direct investment generate positive spillovers? A meta-analysis. Journal of International Business Studies 2009, Vol. 40, p. 1075 - 1094 [Online] Available from: https://link.springer.com/article/10.1057/jibs.2008.111 (Accessed: 6 October 2021)

27.Lagendijk, A. \& Hendrikx, B. Foreign Direct Investment. International Encyclopedia of Human Geography 2009, p. 243 - 254 [Online] Available 
from:

https://www.sciencedirect.com/science/article/pii/B97800804491040016 7X (Accessed: 7 October 2021)

28.Shah, S. Z., Stark, A. W., \& Akbar, S. Firm size, sector and market valuation of R\&D expenditures. Applied Financial Economics Letters, Vol. 4, No. 2, p. $\quad 87-\quad 91$ [Online] Available from: https://www.researchgate.net/publication/46527159 Firm size sector a nd market valuation of RD expenditures (Accessed: 7 October 2021)

29.Saunders, M., Lewis, P., Thornhill, A. \& Bristow, A., 2019. Research Methods for Business Students. 8th ed. s.1.: Pearson Education.

30.Crossley, J. \& Jansen, D., 2021. Saunder's Research Onion: Explained Simply.

[Online] Available from: https://gradcoach.com/saunders-research-onion/ [Accessed 6 October 2021].

31.Wiles, R., Crow, G. \& Pain, H. Innovation in qualitative research methods: A narrative review. Sage Journals, Vol. 11, No. 5, p. 587 - 604 [Online] Available from: https://journals.sagepub.com/doi/abs/10.1177/1468794111413227 (Accessed: 7 October 2021)

32.Bhat, A., 2020. Qualitative research: Definition, Types, methods and examples. [Online] Available at: https://www.questionpro.com/blog/qualitative-researchmethods/

[Accessed: 6 October 2021].

33.Warren, K., 2020. Qualitative Data Analysis Methods 101. [Online] Available at: https://gradcoach.com/qualitative-data-analysis-methods/ [Accessed: 7 October 2021]. 
34.Grabowska, M. Innovative activities in enterprises from the standpoint of cluster initiative. Management, Enterprise and Benchmarking in the $21^{\text {st }}$ Century, 2015, 159 - 168 [Online] Available from Springer (uni-obuda.hu) (Accessed: 7 October 2021)

35.The Coca-Cola Company, 2021. Our Company [Online] Available from: https://www.coca-colacompany.com/company (Accessed: 15 October 2021)

36.The Coca-Cola Company. FAQ [Online] Available from: https://www.cocacolacompany.com/faqs (Accessed: 15 October 2021)

37.The Coca-Cola Company, 2021. FAQ [Online] Available from: https://www.coca-colacompany.com/company/leadership (Accessed: 15 October 2021)

38.The Coca-Cola Company, 2021. Coca-Cola Reports Second Quarter 2021 Results [Online] Available from: https://www.cocacolacompany.com/press-releases/coca-cola-reports-second-quarter-2021results (Accessed: 15 October 2021)

39.Butler, R. A, 2021. How Coca-Cola stacks up against new entrants. [Online] Available from: https://www.investopedia.com/articles/markets/120915/analyzingporters-5-forces-cocacola.asp (Accessed: 16 October 2021)

40.PepsiCo, 2020. Product Information. [Online] Available from: https://www.pepsico.com/brands/product-information (Accessed: 16 October 2021)

41.Statista, 2020. Keurig Green Mountain - Statistics \& Facts. [Online] Available from: https://www.statista.com/topics/2235/keurig-greenmoutain/\#topicHeader wrapper (Accessed: 15 October 2021)

42.Keurig Dr Pepper, 2021. Our Family of Brands. [Online] Available from: https://www.keurigdrpepper.com/en/our-brands (Accessed: 16 October 2021) 
43.Tropicana, 2021.Products [Online] Available from: https://www.tropicana.com/products (Accessed: 14 October 2021)

44.Britvic, 2021. Our Brands [Online] Available from: https://www.britvic.com/our-brands (Accessed: 16 October 2021)

45.Red Bull, 2021. Energy Drink [Online] Available from: https://www.redbull.com/ng-en/ (Accessed: 16 October 2021)

46.Monster Beverage Corporation, 2021. Brands [Online] Available from: https://www.monsterbevcorp.com/\# (Accessed: 17 October 2021)

47.Fever-Tree, 2021. Products [Online] Available from: https://fevertree.com/en GB/products (Accessed: 17 October 2021)

48.Statista, 2021. Non-alcoholic beverages [Online] Available from: https://www.statista.com/markets/415/topic/997/non-alcoholicbeverages/\#overview (Accessed: 17 October 2021)

49.Fortune Business Insights, 2017. Non-alcoholic beverages market size, share \& COVID-19 impact analysis, by type (carbonated soft drinks, RTD coffee \& tea, bottled water, and fruit beverages), distribution channel (supermarket/hypermarket, food services sector, convenience stores, specialty stores, and online retails), and regional forecast, 2020-2027. [Online] Available from: https://www.fortunebusinessinsights.com/industry-reports/non-alcoholicbeverages-market-101927 (Accessed: 15 October 2021)

50.Eduardo, M, 2007. The analysis of five competitive forces of non-alcoholic beverage industry and e-commerce industry cases at the global level. Munich Personal RePEc Archive. [Online] Available from: https://mpra.ub.unimuenchen.de/3077/1/MPRA paper 3077.pdf (Accessed: 17 October 2021) 51.Khan, A. A \& Jayadi, R. Porter five forces analysis on Coca-Cola. Binus University Graduate Program [Online] Available from: https://mmsi.binus.ac.id/2020/06/30/porter-five-forces-analysis-on-cocacola/ (Accessed: 15 October 2021] 
52.Conway, J, 2021. Brand Value of the most valuable soft drink brands worldwide 2021. [Online] Available from: https://www.statista.com/statistics/273063/leading-15-most-valuableglobal-soft-drink-brands-based-on-brand-value/ (Accessed: 16 October 2021)

53.Business Standard, 2021. Coca-Cola sued for downplaying health risks of sugary drinks. [Online] Available from: https://www.businessstandard.com/article/companies/coca-cola-sued-for-downplaying-healthrisks-of-sugary-drinks-117010500278 1.html (Accessed: 16 October 2021)

54.Nace, T, 2019. Coca-Cola named the world's most polluting brand in plastic waste audit. [Online] Available from: https://www.forbes.com/sites/trevornace/2019/10/29/coca-cola-namedthe-worlds-most-polluting-brand-in-plastic-wasteaudit/?sh=2007b3f274e0 (Accessed: 16 October 2021)

55.Flaharty, R, 2021. Coca-Cola it's time to stop your pollution at source. [Online] Available from: https://www.greenpeace.org/international/story/47293/coca-cola-itstime-to-stop-your-pollution-at-source/ (Accessed: 16 October 2021)

56.Business Standard, 2021. Challenges remain in India but recovery signs in away-from-home: Coca-Cola [Online] Available from: https://www.business-standard.com/article/companies/challengesremain-in-india-but-recovery-signs-in-away-from-home-coca-cola121021001797 1.html (Accessed: 17 October 2021)

57.The Coca-Cola Company, 2021. Streamlined portfolio of brands, marketing and innovation to power Coke's 2021 strategy [Online] Available from: https://www.coca-colacompany.com/news/2021-marketing-innovationportfolio-strategy (Accessed: 16 October 2021)

58.The Coca-Cola Company, 2020. How Coca-Cola is rethinking disruptive innovation to anticipate tomorrow's taste [Online] Available from: 
https://www.coca-colacompany.com/news/how-coca-cola-is-rethinking-

disruptive-innovation-to-anticipate-tomorrows-taste (Accessed: 16 October 2021)

59.United Nations Conference on Trade and Development, 2013. Investing in innovation for development [Online] Available from https://unctad.org/system/files/official-document/ciid21 en.pdf

(Accessed: 15 October 2021)

60.Erdal, L \& Gocer, I, 2015. The effects of foreign direct investment on R\&D and Innovations: Panel data analysis for developing Asian Countries. World Conference on Technology, Innovation and Entrepreneurship, Procedia Social and Behavioral Sciences, p. 749 - 758 [Online] Available from file://C:/Users/USER/Downloads/the-effects-of-foreign-directinvestment-on-r-d-and-innovations-panel-data-analysis-for-developingasian-countries.pdf (Accessed: 19 October 2021)

61.MGaleeva, G \& Kadeeva, E. N, 2021. Problems of attracting foreign direct investment into the regional economy. Journal of Physics: Conferences

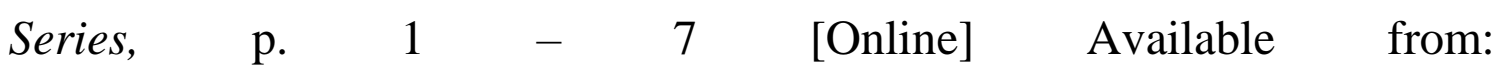
file:///C:/Users/USER/Desktop/Beeds\%20Consulting/Ikeagwu\%20Precious /MGaleeva 2021 J. Phys. Conf. Ser. 1730 012118.pdf (Accessed: 20 October 2021)

62.Donciu, E. C, 2014. Promoting and attracting foreign direct investment. CES working papers, p. 18 - 28 [Online] Available from: https://core.ac.uk/download/pdf/25584403.pdf (Accessed: 21 October 2021)

63.Morisset, J \& Andrews-Johnson, K, 2004. The effectiveness of promotion agencies at attracting foreign direct investment. Foreign Investment Advisory Service, $\quad$ p. $\quad 1 \quad-93$ [Online] Available from: https://documents1.worldbank.org/curated/en/588311468780303317/pd f/271500PAPEROEf1fOpromotionOagencies.pdf (Accessed: 22 October 2021) 
64.Onstad, E, 2019. Plastic bottles vs. aluminum cans: Who'll win the global water fight? [Online] Available from: https://www.reuters.com/article/usenvironment-plastic-aluminium-insight-idUSKBN1WWOJ5 (Accessed: 21 October 2021)

65.Siemens, 2019. Blockchain in the food and beverage industry [Online] Available from: https://news.koreaselection.com/ilsikorea/wpcontent/uploads/sites/3/2021/02/Blockchain-in-the-food-and-beverageindustry.pdf (Accessed: 21 October 2021)

66.Mansor, M. F, Halim, H. A. \& Ahmad, N. H., 2018. Leveraging crowdsourcing practices in small and medium enterprises (SMEs). Journal of Enterpreneurship Education, 21(4), pp. 1-11

67.Edgecomb, C., 2013. 5 Brands effectively implementing social media crowdfunding.

[Online]

Available from: https://www.impactplus.com/blog/5-brands-effectivelyimplementing-social-media-crowdsourcing (Accessed: 21 October 2021)

68.Howe, J., 2006. The rise ofcrowdsourcing. Wired Magazine, 14(6), pp. 1-4.

69.Fry, E., 2018. 4 reasons to keep an eye on your competitor' social media. [Online]

Available from: https://tworiversmarketing.com/blog/4-reasons-keep-eyecompetitors-social-media (Accessed: 20 October 2021)

70.Info Entrepreneurs, 2009. Understand your Competitors. [Online] Available from:

https://www.infoentrepreneurs.org/en/guides/understand-yourcompetitors/(Accessed: 21 October 2021).

71.Davis, J., 2016. Social media gives consumers and brands a direct connection.

[Online]

Available from: https://ducttapemarketing.com/empowerment-socialmedia/ (Accessed: 21 October 2021).

72.Caramela, S., 2020. Social media offers a way to provide great customer service around the clock.

[Online] 
Available from: https://www.businessnewsdaily.com/5917-social-mediacustomer-service.html [Accessed: 20 October 2021].

73.MacDonald, S., 2021. Why customer complaints are good for your business. [Online]

Available from: https://www.superoffice.com/blog/customer-complaintsgood-for-business/[Accessed: 20 October 2021].

74.Huang, W., 2018. How Customer Service can turn angry customers intoo loyal ones. [Online] Available from: https://hbr.org/2018/01/how-customer-service-can-turnangry-customers-into-loyal-ones [Accessed: 21 October 2021].

75.Weber, A., 2011. Soft drink and canning. [Online] Available from: https://www.iloencyclopaedia.org/contents/part-x-96841/beverageindustry (Accessed: 20 October 2021)

76.Yarmolyuk-Krock, K, Skoryk, M, \& Andreyev, V, 2019. Implementation of the EU-Ukraine association agreement. [Online] Available from: http://library.fes.de/pdf-files/bueros/ukraine/15764.pdf (Accessed: 20 October 2021).

77. Organization of Economic Co-operation and Development, 2002. Foreign Direct Investment for Development [Online] Available from: https://www.oecd.org/investment/investmentfordevelopment/1959815.p df Accessed: 29 October 2021)

78.The Coca-Cola Company, 2021. U.S. Racial Equity [Online] Available from: https://www.coca-colacompany.com/shared-future/diversity-andinclusion/racial-equity (Accessed: 30 October 2021)

79.The Coca-Cola Company, 2021. Core Values [Online] Available from: https://www.coca-colacompany.com/shared-future/people-values (Accessed: 30 October 2021)

80.Lalli, P, 2021. The Coca-Cola Company's Commitment on Human Rights. Congressional-Executive Commission on China [Online] Available from: 
https://www.cecc.gov/sites/chinacommission.house.gov/files/documents/ CECC\%20Testimony\%20-\%20Paul\%20Lalli 0.pdf (Accessed: 30 October 2021)

81.Cheng, D, 2013. The development of the service industry in the modern economy: Mechanisms and implications for China. China Finance and Economic Review [Online] Available from: https://chinafinanceandeconomicreview.springeropen.com/track/pdf/10.1 186/2196-5633-1-3.pdf (Accessed 31 October 2021)

82. Adetokunbo, A. M, \& Edioye, P. O, 2020. Response of economic growth to the dynamics of service sector in Nigeria. Future Business Journal [Online] Available from: https://fbj.springeropen.com/track/pdf/10.1186/s43093020-00018-9.pdf (Accessed 31 October 2021)

83.Nations Encyclopedia, 2016. Ukraine - Services. [Online] Available from: https://www.nationsencyclopedia.com/economies/Europe/UkraineSERVICES.html (Accessed 31 October 2021) 